\title{
Direct solid-phase radioimmunoassay of cortisol
}

Citation for published version (APA):

Gijzen, A. H. J. (1977). Direct solid-phase radioimmunoassay of cortisol. [Doctoral Thesis, Maastricht University]. Rijksuniveriteit Limburg. https://doi.org/10.26481/dis.19770520ag

Document status and date:

Published: 01/01/1977

DOI:

10.26481/dis.19770520ag

Document Version:

Publisher's PDF, also known as Version of record

\section{Please check the document version of this publication:}

- A submitted manuscript is the version of the article upon submission and before peer-review. There can be important differences between the submitted version and the official published version of record.

People interested in the research are advised to contact the author for the final version of the publication, or visit the DOI to the publisher's website.

- The final author version and the galley proof are versions of the publication after peer review.

- The final published version features the final layout of the paper including the volume, issue and page numbers.

Link to publication

\footnotetext{
General rights rights.

- You may freely distribute the URL identifying the publication in the public portal. please follow below link for the End User Agreement:

www.umlib.nl/taverne-license

Take down policy

If you believe that this document breaches copyright please contact us at:

repository@maastrichtuniversity.nl

providing details and we will investigate your claim.
}

Copyright and moral rights for the publications made accessible in the public portal are retained by the authors and/or other copyright owners and it is a condition of accessing publications that users recognise and abide by the legal requirements associated with these

- Users may download and print one copy of any publication from the public portal for the purpose of private study or research.

- You may not further distribute the material or use it for any profit-making activity or commercial gain

If the publication is distributed under the terms of Article $25 \mathrm{fa}$ of the Dutch Copyright Act, indicated by the "Taverne" license above, 
DIRECT SOLID-PHASE RADIOIMMUNOASSAY OF CORTISOL 
promotor : Prof. Dr. H.C. Hemker coreferenten: Dr. P.J. Brombacher

Dr. J.H.H. Thijssen 


\title{
ACADEMISCH PROEFSCHRIFT
}

ter verkrijging van de graad van doctor in de geneeskunde

aan de Rijksuniversiteit Limburg te

Maastricht, op gezag van de rector magnificus

Prof. Dr. H.A. Tiddens, Hoogleraar in de faculteit der Geneeskunde, volgens besluit van het college van Dekanen in het openbaar te verdedigen op vrijdag 20 mei 1977 te 16.00 uur in het hoofdgebouw der universiteit Tongersestraat 53

door

\author{
ARNOLD HUBERT JOHAN GIJZEN \\ geboren te Geleen in 1932
}


LEUNEKE

DAAN

SABINE

JEROEN 
Het is mij een waar genoegen $u$ allen te bedanken, die op een of andere manier hebben bijgedragen aan het tot stand komen van dit proefschrift.

Mijn speciale dank gaat uit naar:

Prof. Dr. H.C. Hemker, die mij zeer gestimuleerd heeft om op een snelle manier dit werk te beëindigen.

Dr. J.H.H. Thijssen, uw welwillende medewerking als door de Medische Faculteit Limburg aangewezen coreferent, alsook uw coöperatieve samenwerking op ander gebied stel ik op hoge prijs.

Dr. P.J. Brombacher, uw enorme bijdrage en uitzonderlijke kennis, waarvan ik al zeer lange tijd heb mogen genieten en uw bereidwilligheid, op te treden als coreferent, waardeer ik ten zeerste.

Heer $\mathrm{H}$. Janssens, voor uw inzet, kennis van zaken en nimmer aflatende interesse bij het verrichten der proeven, voel ik mij ten zeerste verplicht.

Het bestuur en de directie van het De Weverziekenhuis te Heerlen ben ik zeer erkentelijk voor de geboden gelegenheid die geleid heeft tot het tot stand komen van dit werk.

Alle medewerkers van het isotopenlaboratorium en de immunologische afdeling van het klinisch chemisch laboratorium voor de vele onderzoeken door u verricht.

Mevrouw M. Poetschlack-Sieler voor het vele en accurate typewerk. 
1. The raising and characterization of cortisol-binding antiserum.

Brombacher, P.J., Gijzen, A.H.J., Janssens, H.H.P., and Soons, M.P.J.: (1975) Clinica Chimica Acta, 58, 173-176 . . . . . . . . . . . . . . .

II. Isolation and purification of cortisol-binding immunoglobulin by affinity chromatography.

Gijzen, A.H.J., Brombacher, P.J., Janssens, H.H.P., and Deckers, S.H.C.M.: (1975) Clinica Chimica Acta, 58, 177-180.

III. Further investigations on the affinity chromatography of unlabeled and labeled cortisol-binding immunoglobulin.

Gijzen, A.H.J.: (1976) Clinica Chimica Acta, 66, 77-84 ..............

IV. Development of a highly specific antiserum and introduction of cellulose coupled immunoglobulin as a solid phase for a direct assay of cortisol in human blood serum.

Gijzen, A.H.J.: (1977) Journal of Molecular Medicine, 2, 99-111

$V$. Specificity and sensitivity of binding proteins in the radio-immuno-assay of cortisol.

A comparative study with several protein binding agents in reactions with many steroids.

Gijzen, A.H.J.: (1977) Journal of Molecular Medicine, 2, 113-118

General survey and conclusions.

Appendix I,

further characterization of the $\mathrm{IgG}$ from the $\mathrm{COA}$-antiserum.

Appendix II,

direct solid phase radio-immuno-assay of cortisol in blood serum . .

Summary

Samenvatting

Curriculum vitae 


\section{Introduction}

With the progress of knowledge of endocrine disorders a growing need exists for an accurate determination of cortisol in plasma. The first generally used fluorometric procedure (1) appeared not to be specific enough for detailed studies of adrenal metabolism, and is rather laborious to perform.

Some years ago, competitive protein binding analyses were introduced ${ }_{n}$ based on the reaction of plasma transcortin with cortisol using a radioactively labelled cortisol derivative as a tracer $(2,3)$.

In our laboratory we tried to combine the sensitivity of a radio assay with the degree of specificity which could be expected in an immunological assay system (4). Immunological methods for the determination of steroids are primarily dependent on the avidity of antibodies directed against a steroid determinant group. For specificity, of course, preference must exist for the particular steroid to be measured, the specificity of the reaction being dependent on the degree of complementary fit of the combining site of the antibody with the steroid concerned. As it is not possible to raise antibodies against such small molecules, it is necessary to synthesize an antigen consisting of the steroid concerned coupled to a macromolecular carrier, e.g. bovine serum albumin (BSA) $(5,6)$.

The steroid-BSA complex can have different steric configurations and for this reason it can be expected that even in the same animal different antibody molecules are raised, in relation to different parts of the steroid molecule. Heterogeneity of antibody population is consequently described by several authors $(7,8)$. The differences in antisera from animals of the same species treated with the same steroid-protein conjugate antigen relate more to the titre of the immunoglobulins produced rather than to their specificity. For this reason, it is not advisable to pool antisera obtained from several rabbits, unless the titres reach approximately the same levels.

In practice, the heterogeneity of the IgG raised against a particular antigen (hapten-carrier conjugate) in a certain animal species is limited. This is explained by the so-called clonal selection theory (9) which states that from many immunoreactive antibody producing cells only a few are stimulated by the antigen with simultaneous repression of immunoglobulin formation by other cells.

Even the formation of crystallisable antibodies is reported, indicating a high degree of homogeneity.

However, the homogeneity of the immunoglobulin in the antiserum is only a first step towards a satisfactory radioimmunoassay. One of the major problems is the influence of non-hapten-binding proteins originating from the antiserum or, in the case of a direct estimation procedure, from the serum sample to be analysed. The coupling reaction of cortisol to the immunoglobulin raised against it is unfavourably influenced by other proteins; this is partly due to a competitive effect of e.g. albumin in the binding reaction.

A direct estimation is nearly impossible on account of transcortin competition. Furthermore, there is often a certain reactivity of the cortisol-binding immunoglobulin towards other steroids. This cross-reactivity is also dependent on the presence of other proteins (10). Decreased cross-reactivity will be seen when the interfering proteins have a stronger affinity for steroids other than cortisol; the reverse is perhaps more likely on account of the relatively high affinity of cortisol for e.g. albumin. For these reasons, we suppose the elimination of proteins (or the inhibition of protein interference by $\mathrm{pH}$ adjustment) to be of great importance in the estimation procedure. Information can be obtained from the affinity constants of cortisol-protein binding reactions with different proteins under different reaction circumstances. 
In radio immuno assays the final separation of bound from free tracer is a source of trouble and loss of accuracy. Quite often the separation is performed by adsorption of that amount of the tracer which is not bound to the antibody (the free fraction) to a separable phase, e.g. dextran-coated charcoal or silicates. The possibility of partial coadsorption of antibody-tracer complex cannot be excluded and is more likely when the incubation period with these agents is prolonged.

To overcome problems in this field, a solid phase coupled with purified immunoglobulin seems to be the binding agent of choice. None of the free tracer left in the solution after completion of the coupling reaction will bind to this insoluble phase, which is removed by centrifugation. In this system, no corrections are needed for the misclassification of "bound in free" or "free in bound" tracers.

The development of a satisfactory cortisol-binding protein to be used in radio immuno assay has been the subject of progressive studies in our laboratory.

The aim of the present investigation was to raise cortisolbinding antiserum which could replace the natural transcortin in the protein binding assay. It was decided to raise antisera in rabbits starting from different antigens, cortisol-BSA conjugates, and to isolate and purify the immunoglobulins contained in the antisera, finally characterising the puriffied cortisol-binding immunoglobulins.

Once a suitable binding protein was obtained, the purpose of the study was to improve and simplify the estimation of cortisol in serum, if possible omitting any extraction procedure and using a solid-phase system for the separation of free and bound radioactivity. This total programme was started by synthesizing two antigens, i.e. cortisol-21-succinyl-BSA (CSA) and cortisol-3-(carboxymethyl)-oxim-BSA (COA), and by immunising rabbits with these antigens.

For the isolation and purification of the immunoglobulins, gel filtration, ion exchange chromatography and affinity chromatography were applied. Carriers for affinity chromatography were synthesised following the principles of the hapten-antibody reaction by preparing covalently bound cortisol-solid-phase compounds. Characterisation of purified immunoglobulins was performed by immuno-diffusion and immunoelectrophoresis techniques.

Solid phase bound immunoglobulins were synthesised to be used in the radio immuno assay. 


\section{References}

1. D. Mattingly. A sinple fluorimetric method for the estimation of free 11 hydrowycorticoids in human plasma.

J. clin. Path. 15, 3740379 (1962).

2. B.E.P. Murphy, Some studies on the protein binding of steroids and their applications to the routhine micro and ultramicro measurement of various steroids in body fluids by competitiwe protein-binding radio-assay.

j. clin. Endocrinol. 27, 973-990 (1967).

3. C.A. Nuguit, D.M. Magus, Plasma corticosteroids determined by use of corticosteroid binding globulin and dextrancoated charcoal.

J. clin. Endocrinol. 26, $1116-1122$ (1966).

4. P.J. Brombacher, A.H.J. Gijzen, H.H.P. Janssens and M.P.J. Soons, The raising and characterization of cortisol-binding antiserum.

Clin. Chim. Acta 58, 173-176 (1974).

5. B.F. Erlanger, F. Borek, S.M. Bieiser, L. Lieberman, Steroid-protein conjugates. I Preparation and characterization of conjugates of bowine serum albumin with testosterone and cortisone. J. biol. Chem. 228, 713.727(1957).

6. B.F. Erlanger, F. Borek, S.M. Beiser, L. Lieberman, Steroid-protein conjugates. II Preparation and characterization of conjugates of bowine serum albumin with progesterone desoxycortisone and estrone. J. biol. Chem. 234, 1090.1094 (1959).

7. G.M. Edelman, W.E. Gall, The antibody problem. Ann. Rev. Biochem. 38, 415-466 (1969).

8. D. Pressman and A.L. Grossberg, (1970) in Immunologic methods in steroid determination. Eds. F.G. Péron and B.V. Caldwell.

Pages 1-11; Plenum Press, N.Y. and London.

9. G.J. w. Nossal, A. Szenberg, G.L. Ada, Caroline M. Austin, Single cell studies on $19 \mathrm{~S}$ antibody production.

J. exp. Med. 119, 485-502 (1964)。

10. J.J. Pratt, W. Koops, M.G. Woldring. T. Wiegmans, Specificity of Immunoassays. I. Effect of plasma proteins in the specificity of steroid immunoassay.

Eur. J. nucl. Med. 1, 37.48 (1976). 
(c) Elgevier Seientific Publishing Company, Amsterdam - Printed in The Netherlands

CCA 6802

\title{
THE RAISING AND CHARACTERIZATION OF CORTISOL-BINDING ANTISERUM
}

\author{
P.J. BROMBACHER, A.H.J. GIJZEN, H.H.P. JANSSENS and M.P.J. SOONS \\ Department of Climical Chemistry and Isotopes Laboratory, De Wever-Zieke mhuis, Heerlen \\ (L.) (The Netherlands)
}

(Received August 21, 1974)

\section{Summary}

Synthesis of a cortisol-albumin compound and the raising of antibodies against cortisol in rabbits are described in detail.

The steroid-protein complex is characterized by a number of reactions regarding the amount of cortisol coupled and the ability of the coupled steroid to react as such.

The specificity of the harvested antiserum and transcortin towards the coupling of several related steroids are compared; the rabbit antiserum appears to be the more sellective binding agent.

\section{Introduction}

The rapidly growing demand for a specific method to estimate the cortisol-content of human plasma recently led to the development of competitive protein binding methods and radio immuno assay procedures. The cortisol binding protein used in the former methods generally is transcortin, which is present in the blood plasma of several animals and man [1]. A disadvantage is the rather poor stability of the protein in a more or less purified state [2] leading to the use of transcortin-containing whole plasma from which the endogenous cortisol is removed by charcoal adsorption [3]. The use of serum from pregnant or estrogen-treated patients is advisable on account of its increased transcortin content. Interference by non-specific plasma proteins remains a source of errors.

In order to reduce aspecific reactions the use of plasma protein fractions rich in transcortin can be considered. We tried several Cohn-fractions [4] of $\alpha$-globulin without great improvement. The use of animal antiserum against. cortisol seemed to be more promising.

The preparation and characterization of such an antiserum are described here in detail, because the techniques we employed may be useful to others 
working on similar problems. A cortisol derivative (cortisol-succinyl-albumin, CSA) is synthesized and used as immunogen in the raising of antiserum in rabbits against the hapten cortisol.

\section{Methods and Results}

\section{Synthesis of the immunogen cortisol-succinyl-albumin (CSA)}

The raising of antisera, in animals, against cortisol as such is impossible on account of the strongly depressing effect of the compound on antibody pro. duction in general. An immunogen has to be prepared by coupling the steroid to a peptide carrier, for which we have chosen bovine albumin on account of its strongly antigenic properties in rabbits. We synthesized cortisol-succinylalbumin (CSA) starting from cortisol-21-hemisuccinic acid and bovine serum albumin. The antiserum produced in those animals against this immunogen appeared to have a strong avidity for the free steroid, which thus reacts as a hapten. The synthesis is a mixed anhydride method [5].

The coupling procedure was performed by adding $0.73 \mathrm{ml}$ of triethylamine to an equimolar quantity $(2.39 \mathrm{~g}, 5.17 \mathrm{mmol})$ of cortisol-hemisuccinate, dissolved in $50 \mathrm{ml}$ of tetrahydrofuran; after the mixture is chilled to $10^{\circ}$ an equimolar quantity $(0.64 \mathrm{ml})$ of isobutylchloroformate is added with stirring during one minute. The reaction mixture is then rapidly added to an alkaline solution of $9 \mathrm{~g}$ of bovine albumin in $400 \mathrm{ml}$ of water/tetrahydrofuran $1: 1(\mathrm{pH}$ 11.0 by adding $350 \mathrm{mg}$ of $\mathrm{NaOH}$ ). The tem perature is brought down to $4^{\circ}$ and the reaction proceeds at that temperature during four hours. After gas-development has stopped and the solution has become clear, the protein derivatives are isolated by gel filtration over Sephadex G25 gel in water. The proteins are precipitated from the eluate $(240 \mathrm{ml})$ by isoelectric precipitation at $\mathrm{pH} 4.5$ during 16 hours at $4^{\circ}$ and subsequent centrifugation, and the residue is redissolved in $15 \mathrm{ml}$ of water adding as much of a molar solution of sodium hydroxide as is necessary to obtain complete solution at $\mathrm{pH} 7.0$. The protein derivatives are then isolated by another gel-filtration run over Sephadex $G 50$ in water and the collected protein-containing fractions are lyophylized. Yield $9 \mathrm{~g}$ of product.

The immunogen prepared in this way is characterized by the following reactions:

a. By repeated extraction of an aqueous solution of the compound with chloroform, no traces of uncoupled or adsorbed steroid could be removed; no free steroid is present.

b. By determination of the nitrogen content of the compound the albumin moiety could be calculated to be $84.7 \%$, from which the number of cortisol groups bound per molecule of albumin could be calculated to be exactly 28 .

c. Electrophoresis of an aqueous solution of the compound $(40 \mathrm{mg} / \mathrm{ml})$ on cellulose acetate at $\mathrm{pH} 8.6$ in acetate $(0.05 \mathrm{~mol} / 1) /$ barbiturate $(0.05 \mathrm{~mol} / 1)$ buffer showed an increase of electrophoretic mobility of $15 \%$ compared to bovine albumin; similar phenomena are reported elsewhere [6]. The synthesized compound appeared to be electrophoretically pure.

d. When an alkaline methanolic solution of tetrazolium blue is added to the synthesized compound, a clear blue color is developed, which proves the 
ability of the hapten-groups to react as cortisol. Solutions of bovine albumin fail to react in this way.

\section{Immunization of rabbits with the prepared immunogen}

The raising of antibodies in animals can be performed in different ways. We chose a widely spread procedure by injecting a mixture of one part of a solution of $10 \mathrm{mg} / \mathrm{ml}$ of the immunogen in physiological saline with four parts of complete Freund's adjuvant. Twice weekly during three subsequent weeks, $0.5 \mathrm{ml}$ of the mixture was administered to the animals in multiple subcutaneous doses and $0.5 \mathrm{ml}$ intramuscularly. After six to eight weeks the avidity of the serum for cortisol was considerable; the ten thousand times diluted serum could be used for radio immuno assay. The serum was characterized by immunodiffusion (Ouchterlony technique [7]) against solutions of bovine albumin and the immunogen CSA; massive clearly different precipitation lines occurred at dilutions of $200 \mathrm{mg} / 1$ of the mentioned antigens against undiluted serum, and precipitation could still be visualized with concentrations as low as $2 \mathrm{mg} / 1$. The injection of CSA evidently raises the production of distinct antibodies against both bovine serum albumin and cortisol-succinyl-albumin. After absorption of the antibody against bovine albumin by adding a surplus of the latter and centrifugation of the formed precipitate, the ability of the remaining serum to react with CSA in the immunodiffusion test was unchanged. This proves the existence of an antibody against the immunogen, which does not react with bovine albumin.

\section{Specificity of the cortisol binding antiserum}

The selectivity of the cortisol binding antiserum in the radio immuno assay was checked against several other steroids. The amount of serum used in the assay was determined by titration with a radioactive cortisol derivative (cortisol21 -succinyl-[ $\left.{ }^{1}{ }^{25} \mathrm{I}\right]$ tyrosine methylester) to bind $50 \%$ of the tracer. In Table I the relative recovery of several steroids is given. The low interference of corticosterone is remarkable and is in contrast with the selectivity of transcortin, which has a lower specificity for most investigated steroids. This is important in

TABLE I

BINDING CAPACITY OF CORTISOL-BINDING SERUM FOR SEVERAL STEROIDS FROM EQUIMOLAR SOLUTIONS

The recovery of added steroid from equimolar solutions is giwen as percentages, A, rabibit antisenum: B, corthol-free muman plasma (transcortin-plasma).

\begin{tabular}{lrr}
\hline & A & B \\
\hline Cortisol & 100 & 78 \\
$11-$ Deoxycortisol & 97 & 100 \\
17-Hydroxyprogesterone & 30 & 58 \\
Progesterone & 41 & 13 \\
Pregnenolone & 0 & 0 \\
Corticosterone & 23 & 85 \\
11-Deoxycorticosterone & 46 & 60 \\
Cortisone & 29 & 24 \\
Tetrahydrocortisol & 6 & 24 \\
\hline
\end{tabular}


those experiments in which the concentrations of corticosterone. and sometimes tetrahydrocortisol (in urine) cannot be neglected.

\section{References}

1 U.S. Seal and F.P. Doe, J. Biol. Chem., 237 (1962) 3136

2 U.S. Seal and R.P. Doe, Endocrinollogy, 73 (1969) 371

3 W. Heyns, H. van Baelen and P. de Moor, Clin. Chim. Acta, 18 (1967) 361

4 E.J. Cohn, L.E. Strong. W.L. Hughes, D.J. Mulford, J.N. A shworth, M. Melin and H.L. Taylor, J. A mn Chem. Soc, $68(1946) 459$

5 B.F. Erianger, F. Bore $k_{、}$ S.M. Beiser and S. Lieberman, J. Biol. Chem 228 (1957) 713

6 S.. Lieberman, B.F. Erlanger, S.M. Beiser, F.J. Agrte, Jr, Rec. Progr. Homone Res., 15 (1959) 165

7 ö. Ouchterlony, Progr. Allergy, 5 (1958) 1 
$\operatorname{CCA} 6803$

\title{
ISOLATION AND PURIFICATION OF CORTISOL-BINDING IMMUNO- GLOBULIN BY AFFINITY CHROMATOGRAPHY
}

\author{
A.H.J. GLUZEN, P.J. BROMBACHER, H.H.P. JANSSENS and S.H.C.M. DECKERS \\ Isotopes Laboratory, De Wever-Ziekenhüs, Heerlen (L.) (The Netherlands)
}

(Received August 21, 1974)

\section{Summary}

Cortisol-binding IgG is isolated from the serum of immunized rabbits by affinity chromatography on sepharose-coupled antigen. The preparation of this solid phase, the chromatography and the reactions to characterize the isolated immunoglobulin are described.

\section{Introduction}

The isolation and purification of specific antibodies from the blood of animals after immunization with a special antigen can be accomplished in many ways. The underlying principle is most often the reaction between the antibody and the antigen against which it has been raised. Much of the usefulness of the procedure then depends on the possibility of breaking up the antigen-antibody complex without denaturation of either component and the succesful separation of the two. Methods to achieve this were described many years ago, based on dissociation of antigen-antibody precipitates or agglutinates [1,2] using strong salt solutions, bases, via complexes with diazo compounds or by (enzymatic) digestion of the antigen moiety [3]. In most cases loss of specific material is unavoidable.

A recent rapidly developing method is affinity chromatography [4]. The antigen is made insoluble by coupling to a solid support but retains its capacity to react with the specific antibody. It is often possible to desorb the antibody from the solid phase coupled antigen by simple elution at a suitable $\mathrm{pH}$. We coupled a complex antigen to sepharose, and used the insoluble reaction product as a support in column chromatography to extract the antibody raised against the mentioned antigen, from the serum of immunized rabbits; the antibody could then be eluted without loss of immunological activity. 


\section{Preparation on the antigen-solid phase complex CSA-sepharose}

The synthesis of the antigen cortisol-succinyl-albumin(CSA) and the raising of rabbit antiserum against it were as previously described [5].

The coupling of CSA to sepharose is done in exactly the same way as described for intrinsic factor coupling [6]. CSA $(3 \mathrm{~g})$ is coupled to Sepharose$4 \mathrm{~B}-\mathrm{CNBr}$-activated $(200 \mathrm{mg})$ in a total volume of $20 \mathrm{ml}$.

The complex obtained in this way is suspended in $\mathrm{NaCl}$ solution $(0.15$ mol/1) containing $0.1 \% \mathrm{NaN}_{3}$ and stored at $4^{\circ}$. The product was characterized by positive reactions with biuret reagent for protein and by reaction with alkaline methanolic tetrazolium blue reagent for cortisol. The coloured reaction products sedimented on standing, on account of the insolubility of the solid phase. The supernatant was colourless which indicates both the coupling of CSA to the sepharose particles, and the remaining ability of the cortisol moiety to react as such. The relative quantity of CSA used in the reaction with sepharose is rather large on account of the limited number of reactive groups in the molecule compared to e.g. bovine albumin; a number of amino groups in albumin are lost in the synthesis of CSA. Uncoupled material is removed by washing.

\section{Affinity chromatography of antiserum}

The CSA-sepharose was packed in a column $12 \mathrm{~cm} \times 0.9 \mathrm{~cm}$ (Pharmacia $\mathrm{K}$ 9/15 column). One $\mathrm{ml}$ of rabbit anticortisol serum was applied and chromatography continued with $20 \mathrm{ml}$ of a Tris buffer $(0.2 \mathrm{M}, \mathrm{pH} 8.0$ containing $0.5 \mathrm{M} \mathrm{NaCl}$ ). All serum proteins except the antibody are thus removed from the column.

The antibody is released from the sepharose-coupled antigen by elution with glycine-HCl buffer $(0.2 \mathrm{M}, \mathrm{pH} 2.8$ containing $0.5 \mathrm{M} \mathrm{NaCl})$. After the first $3 \mathrm{ml}$ of eluate are discarded, the antibody (immunoglobulin) is collected in the next $4 \mathrm{ml}$ (Table I). The $\mathrm{pH}$ of the eluate is restored to 7.0 to prevent denatu-

\section{TABLE I}

ABSORBANCE (280 nm) OF ELUATES FROM SEPHAROSH-ANTIGHN COLUMN ON APPLICATION OH HABIT ANTISERUM

\begin{tabular}{llll}
$\begin{array}{l}\text { Fraction } \\
\text { No. }\end{array}$ & $\begin{array}{l}\text { Tris buffer } \\
(\mathrm{pH} 8.0)\end{array}$ & $\begin{array}{l}\text { Fraction } \\
\text { No }\end{array}$ & $\begin{array}{l}\text { Glycine buffer } \\
\text { (pH 2.8) }\end{array}$ \\
\hline 1 & 0.002 & 11 & 0.004 \\
2 & 0.015 & 12 & 0.010 \\
3 & 0.840 & 13 & 0.030 \\
4 & 2.000 & 14 & 0.390 \\
5 & 0.615 & 15 & 0.555 \\
6 & 0.033 & 16 & 0.230 \\
7 & 0.030 & 17 & 0.160 \\
8 & 0.018 & 18 & 0.040 \\
9 & 0.011 & 19 & 0.027 \\
10 & 0.007 & 20 & 0.012
\end{tabular}

Note: with Tris buffer faction wolume $2 \mathrm{ml}$; after elution with $20 \mathrm{~m}$ l of Tris huffer, elution with butfer is started (fraction volume $1 \mathrm{mil}$ ). 


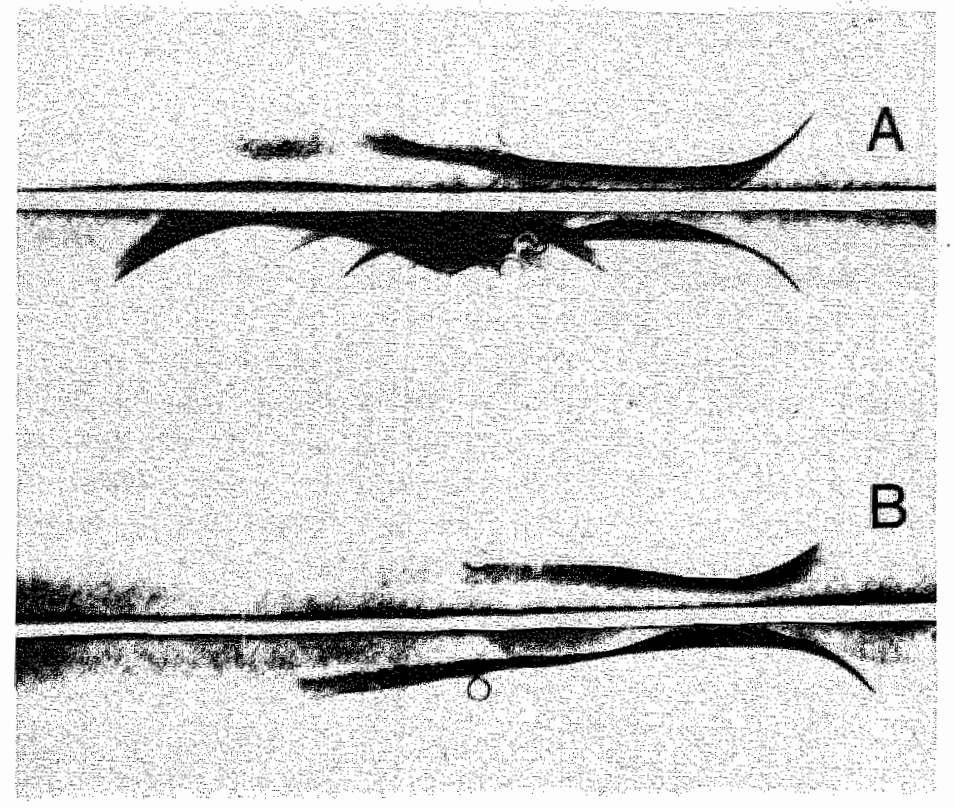

Fig. 1. Immunowectrophoresis of eluted immunoglobulin (upper patterns) and whole rabbit senum (low patterns) i the central well contains a polyvahent goat-anti-rabbit serum (A) or goat-anti-rabbit-lgG (B Electrophoresis at $30 \mathrm{~V} / \mathrm{cm}$; barbital buffex $0.05 \mathrm{M}$, pH 8.6 medium $1 \%$ agar.

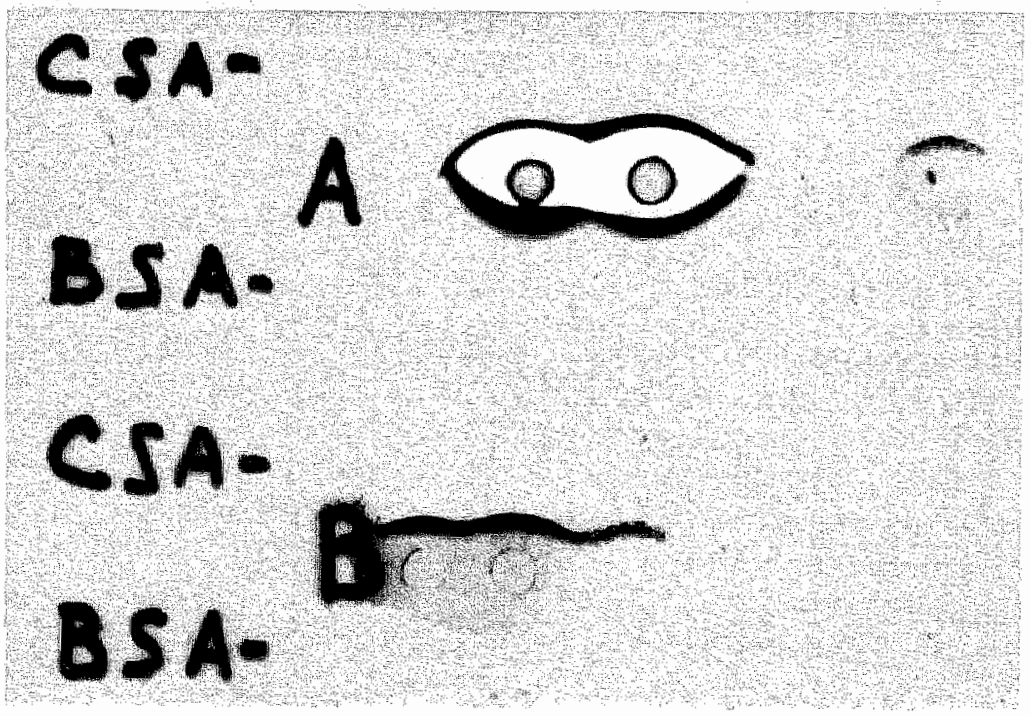

Fig. 2. Immunodifusion pattern of eluted immunoglobulin fractions (centre holes) against CSA and BSA A, from rabbit antiserum; $B$, from rabbit antiserum aftex absorption with BSA. Ouchterlony technique diffusion in agar ( 1 , gel in buffer. 
ration. The immunoglobulin was detected by spectrophotometry at $280 \mathrm{~nm}$ and demonstrated by immunoelectrophoresis to be rabbit IgG (Fig. 1) and by immunodiffusion (Ouchterlony technique) to be reactive towards CSA and towards bovine serum albumin (BSA). The IgG collected consists of two components at least; the antibody against. BSA can be absorbed and removed by centrifugation of the precipitated complex by adding to the eluate $5 \mathrm{mg}$ of BSA per $\mathrm{ml}$ rabbit serum applied to the column. The supernatant solution now contains only CSA-reactive antibody (Fig. 2). The precipitation of the antibody against BSA does not affect the antibody against CSA on account of the structure of the latter. The binding of cortisolhemisuccinate to the albumin molecule in the CSA complex prevents the latter reacting with anti-albumin immunoglobulin. Similar phenomena have been mentioned elsewhere [7]. After lyophylization the immunoglobulin can be stored at $4^{\circ}$ for several months without loss of activity. The procedure described is simple to perform and can be applied to many similar problems in this field. This is of special importance for the rapid development of radio immuno assay procedures requiring purified and specific antibodies to obtain sufficient sensitivity in the assay.

\section{References}

1 M. Heidelberger and F.E. Kendall, J. Exp. Med., 64 (1936) 161

2 M. Heidelberger and E.A. Kabat, J. Exp. Med.. 67 (1938) 181

3 E.A. Kabat, in E.A. Kabat and M.M. Mayer (Eds), Experimental Immunochemistry "Charles C. Thomas, Springfield, 111., U.S.A., 1961, p. 781

4 P. Cuatrecasas and C.B. Anfinsen, Ann. Rev. Biochem., 40 (1971) 259

5. P.J. Brombacher, A.H.J. Gizen, H,H,P. Janssens and M.P.J, Soons, Clin. Chim. Acta, 58 (1975) 173

6 P.J. Brombacher, A.H.J. Gijzen and M.P.J, Soons, Clin. Chim. Acta, 52 (1974) 311

7 E.A. Kabat, in E.A. Kabat and M.M. Mayer (Eds), Expezimental Immunochemistry. Charles C. Thomas, Springfield, 111., U.S.A., 1961, p. 455 
CCA 7471

\section{FURTHER INVESTIGATIONS ON THE AFFINITY CHROMATOGRAPHY OF UNLABELED AND LABELED CORTISOL-BINDING IMMUNOGLOBULIN}

\section{A.H.J.GIZEN}

Isolopes Laboratory, DeWever-Zickenhuis, Meerlen (The Netherlands)

(Received August 4, 1975)

\section{Summary}

A specific method for the isolation of cortisol-binding immunoglobulin from rabbit antiserum by affinity chromatography on sepharose-coupled haptene (sepharose-cortisol) is described. This isolation technique has the advantage that no nonspecific $\gamma$-globulin is present in the eluate of the column; previous absorption of anti-BSA-globulin can be omitted. The nature of the isolated immunoglobulin is determined by immuno-electrophoresis.

The same isolation procedure can be used for the purification of radioactive antibody for radioimmunometric assay after labeling the immunoglobulin with iodine-125.

\section{Introduction}

In previous publications we described the preparation [1] and purification [2] of cortisol-binding immunoglobulin. The latter was produced in rabbits using cortisol-succinyl-bovine albumin as an antigen (CSA), synthesized from cortisol and bovine serum albumin (BSA). The $\gamma$-globulin produced was isolated from the rabbit serum by affinity chromatography on solid phase sepharose-CSA complex. This resulted in the isolation of both cortisol-binding globulin and anti-BSA globulin.

As a first hypothesis it might be expected that by affinity chromatography on solid phase sepharose-cortisol complex not containing albumin, a better isolation of cortisol-binding $\gamma$-globulin as such could be achieved. In fact affinity chromatography on sepharose-CSA yields both anti-BSA-globulin and cortisol-binding anti-CSA globulin. For the isolation of the latter the anti-BSA globulin has to be absorbed by adding either a surplus amount of BSA and removal of the formed antigen-antibody complex by centrifugation, or by adsorption of the anti-BSA globulin to polymerized bovine serum albumin. The 
latter substance can be prepared by polymerization with glutaric dialdehyde. In both procedures, however, considerable loss of cortisol-binding anti-CSA globulin occurs.

In order to obtain a better yield of the hapten-binding globulin the antiCSA globulin was isolated by affinity chromatography on sepharose-cortisol to which anti-BSA globulin is not bound. The procedure is described in this paper.

A second hypothesis was that the rabbit cortisol-binding immunoglobulin in vivo carries a certain amount of endogenous cortisol. If this should be true, the "loaded" protein cannot be isolated via sepharose-cortisol because the cortisol-binding sites are already occupied. A higher yield of specific globulin might be expected by removing the cortisol from the rabbit serum prior to affinity chromatography; this could be done by e.g. active charcoal adsorption [3] or by florisil adsorption. The validity of this hypothesis was investigated but could not be proved in this study.

\section{Materials and methods}

Cortisol binding rabbit antiserum was prepared as described in our previous paper [1].

\section{Solid phase hapten complex: sepharose-cortisol}

The preparation of the solid phase to be used in the affinity chromatography is as follows. The recent availability of aminoalkylsepharose (AHSepharose 4-B, Pharmacia ${ }^{\circledR}$ ) created the possibility of coupling cortisol-hemisuccinate to the solid phase sepharose. It can be expected on account of the presence of the alkyl chains that the prepared product has such a steric structure that binding to macromolecules in affinity chromatography is possible.

Synthesis. $5 \mathrm{~g} \mathrm{(20} \mathrm{ml} \mathrm{gel)} \mathrm{of} \mathrm{AH-Sepharose} \mathrm{4-B} \mathrm{are} \mathrm{left} \mathrm{to} \mathrm{swell} \mathrm{in} 50 \mathrm{ml}$ of $0.5 \mathrm{M} \mathrm{NaCl}$ solution in water for one hour at $20^{\circ}$. The substance is then washed with $1000 \mathrm{ml}$ of the $\mathrm{NaCl}$ solution to remove stabilizers (dextran etc.) present in the original product. This washing is performed by gentle suction over a G4 glass filter covered by a disc of filter paper to prevent obstruction of the porous glass filter. A second washing is done with $200 \mathrm{ml}$ of water to remove the sodium chloride. The washed gel (volume about $10 \mathrm{ml}$ ) is added whilst stirring to $15 \mathrm{ml}$ of tetrahydrofuran and thoroughly mixed. The mix ture is chilled in melting ice to $0^{\circ} \mathrm{C}$ and the $\mathrm{pH}$ adjusted to 11.0 by adding a required amount of $\mathrm{NaOH}$ solution, 2 molar in water. Next a solution of $100 \mathrm{mg}$ of cortisol-hemisuccinate in $2 \mathrm{ml}$ of tetrahydrofuran is prepared to which is added $0.4 \mathrm{ml}$ of a $20 \%(\mathrm{v} / \mathrm{v})$ solution of tri- $n$-butylamine in tetrahydrofuran, and $0.4 \mathrm{ml}$ of a $10 \%(\mathrm{v} / \mathrm{v})$ solution of isobutylchloroformate in tetrahydrofuran. The mixture is left at $0^{\circ} \mathrm{C}$ for $30 \mathrm{~min}$, whereupon this "activated" cortisolhemisuccinate solution is added dropwise to the above-described suspension of washed $\mathrm{AH}$-sepharose gel in tetrahydrofuran.

After two hours" reaction at $0^{\circ} \mathrm{C}$ (melting ice bath) the $\mathrm{pH}$ of the mix ture has changed to 7.5 which indicates the end of the coupling procedure. The reaction product sepharose-alkyl-succinyl-cortisol ("sepharose-cortisol" solid phase) is then washed three times with $100 \mathrm{ml}$ portions each of $50 \%$ watertetrahydrofuran mixture, in order to remove excess unreacted cortisol-hemi- 
succinate. Next it is washed with three $100 \mathrm{ml}$ portions of water, then with three $100 \mathrm{ml}$ portions of a 0.1 molar solution of $\mathrm{NaHCO}_{3}$ in water, then with one $500 \mathrm{ml}$ portion of a mixture of water/ethanol $50 \%(\mathrm{v} / \mathrm{v})$ and finally with one $500 \mathrm{ml}$ portion of water. After these washings the solid phase is suspended in $20 \mathrm{ml}$ of sodium phosphate buffer solution 0.15 molar, $\mathrm{pH} 6.0$ containing $0.1 \% \mathrm{NaN}_{3}$, and stored at $4^{\circ} \mathrm{C}$.

The product was characterized by reaction of the solid phase with alkaline methanolic tetrazolium blue reagent to confirm the presence of reactive cortisol residues. The coloured reaction product can be centrifuged; the supernatant solution remains colourless, indicating the absence of free cortisol. It can be calculated from the data accompanying the $\mathrm{AH}$-Sepharose gel that the maximum amount of cortisol hemisuccinate which can be coupled to $20 \mathrm{ml}$ of gel is about $80 \mathrm{mg}$. A method for the quantitative analysis of the cortisol content of the solid phase is under development.

\section{Affinity chromatography of antiserum}

The sepharose-alkylamino-succinyl-cortisol obtained by the aforegoing synthesis, is packed in a column $12 \mathrm{~cm} \times 0.9 \mathrm{~cm}$ (Pharmacia K9/12 column). The column is equilibrated with Tris buffer, 0.03 molar, $\mathrm{pH} 7.4$. Lyophilized rabbit antiserum (100 $\mathrm{mg}$ ) is dissolved in $2 \mathrm{ml}$ of the same Tris buffer. This solution is applied to the column and chromatography is continued with $80 \mathrm{ml}$ of the Tris buffer. Serum proteins except the cortisol-binding immunoglobulin are thus removed from the column [2]. The antibody is released from the

\section{TA BLE I}

ISOLATION OF CORTISOL-BINDING (ANTI-CSA) GLOBULIN BY AFFINITY CHROMATOGRAPHY ON SEPHAROSE-CORTISOL (WITHOUT INCUBATION WTTH THE SOLID PHASE). ABSORBANCE (280 NM) OF ELUATES FROM SEPHAROSE-CORTISOL COLUMN $12 \mathrm{CM} \times 0.9 \mathrm{CM}$

I , from rabbit antiserum (100 $\mathrm{mg}$ dry protein) dissolved in $2 \mathrm{ml}$ of Tris buffer, $\mathrm{pH} 7.4$.

II, from rabbit antiserum (100 $\mathrm{mg}$ dry protein) after dilution with Tris buffer, pH 7.4 to $22 \mathrm{ml}$. Fraction wolume of each sample is $3 \mathrm{ml}$. A: Tris buffer, $\mathrm{pH} 7.4$. B: glycine buffer, $\mathrm{pH} 2.8$.

\begin{tabular}{|c|c|c|c|c|c|c|c|}
\hline \multicolumn{4}{|l|}{1} & \multicolumn{4}{|l|}{ III } \\
\hline $\begin{array}{l}\text { Fraction } \\
\text { No. }\end{array}$ & $A$ & $\begin{array}{l}\text { Fraction } \\
\text { No. }\end{array}$ & B & $\begin{array}{l}\text { Fraction } \\
\text { No. }\end{array}$ & A & $\begin{array}{l}\text { Fraction } \\
\text { No. }\end{array}$ & $\mathrm{B}$ \\
\hline 1 & 0.024 & 27 & 0.100 & 1 & 0.053 & 22 & 0.098 \\
\hline 2 & 0.022 & 28 & 0.118 & 2 & 0.056 & 23 & 0.092 \\
\hline 3 & 1.380 & 29 & 1.400 & 3 & 0.145 & 24 & 0.700 \\
\hline 4 & 4.000 & 30 & 1.970 & 4 & 0.475 & 25 & 0.530 \\
\hline 5 & 1.480 & 31 & 0.295 & 5 & 0.660 & 26 & 0.140 \\
\hline 6 & 0.960 & 32 & 0.147 & 6 & 0.770 & 27 & 0.098 \\
\hline 7 & 0.620 & 33 & 0.086 & 7 & 0.860 & 28 & 0.068 \\
\hline 8 & 0.455 & 34 & 0.060 & 8 & 0.910 & 29 & 0.060 \\
\hline 9 & 0.355 & 35 & $0.046^{\circ}$ & 9 & 0.940 & & \\
\hline 10 & 0.293 & 36 & 0.038 & 10 & 0.910 & & \\
\hline 11 & 0,250 & & & 11 & 0.525 & & \\
\hline 12 & 0.225 & & & 12 & 0.280 & & \\
\hline $\mathbb{1 3}$ & 0.195 & & & 13 & 0.222 & & \\
\hline 14 & 0.195 & & & 14 & 0.170 & & \\
\hline 15 & 0.195 & & & 15 & 0.144 & & \\
\hline 26 & 0,100 & & & 21 & 0.075 & & \\
\hline
\end{tabular}




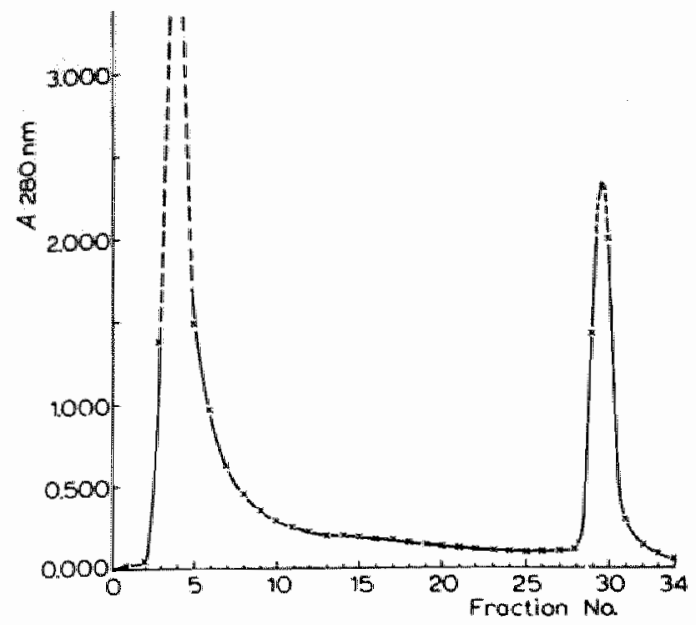

Fig. 1. Affinity chromatography elution pattem from rabbit anti-semm over sepharose-cortisol. Fraction nos $29-31$ are collected, desalted on Sephadex G-25 and ly ophilizised.

sepharose-coupled cortisol by elution with glycine/ $\mathrm{HCl}$ buffer $(0.2 \mathrm{M}, \mathrm{pH} 2.8$ containing $0.5 \mathrm{M} \mathrm{NaCl}$ ). After discarding the first eluate the antibody fraction is collected (Table I, Fig. 1). The pH of the eluate is restored to 7.0 to prevent denaturation of the protein. The eluate from the column contained $\gamma$-globulin and a small amount of albumin, as demonstrated by immuno-electrophoresis (Fig. 2). This can be explained by assuming that during the affinity chromatography at $\mathrm{pH} 7.4$ the $\gamma$-globulin is bound to the solid phase and some albumin is retained by nonspecific adsorption on the column.

For further purification the $\gamma$-globulin-containing eluate is passed through a column of Biogel P-100 (crosslinked polyacrylamide), thus removing smaller proteins and salts, with water as an eluent (Table II). The fractions containing the immunoglobulin are lyophilized and the dry protein is stored at $-20^{\circ} \mathrm{C}$. The total yield is $10-15 \mathrm{mg}$ of cortisol-binding immunoglobulin. By immunoelectrophoresis it was found that some albumin is still present in the preparation even after the described purification procedures. The amount of immunoglobulin obtained is larger than the amount from the same quantity of rabbit antiserum obtained by affinity chromatography over sepharose-CSA. In that

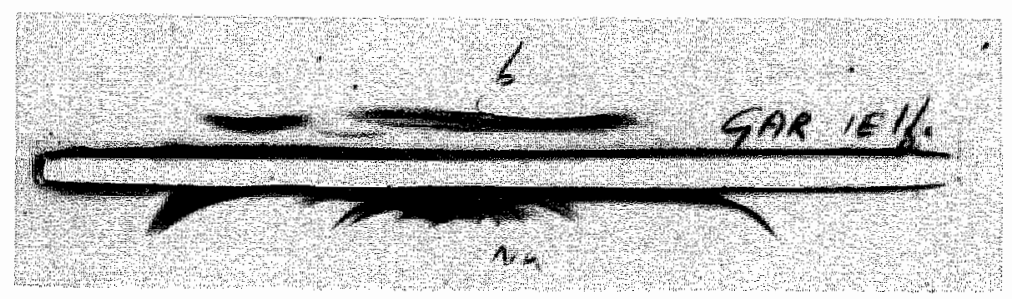

Fig. 2. Immunoelectrophoresis of cortisol-binding immunoglobulin. Upper pattern: immunoghobulin solution. Central well: polyvalent antiserum goat-anti-rabbit. Lower pattern: full rabbit serum. 


\begin{tabular}{ll}
\hline Fraction No. & Absorbance \\
\hline 1 & 0.022 \\
2 & 0.012 \\
3 & 0.044 \\
4 & 0.685 \\
5 & 0.790 \\
6 & 0.177 \\
7 & 0.054 \\
8 & 0.032 \\
9 & 0.028 \\
10 & 0.034 \\
11 & 0.032 \\
12 & 0.032 \\
13 & 0.034 \\
14 & 0.034 \\
15 & 0.029 \\
16 & 0.029 \\
\hline
\end{tabular}

procedure we never obtained more than half the amount that has been obtained now. The validity of the first hypothesis is clearly demonstrated.

The same procedure was then applied to cortisol-free rabbit antiserum which was prepared as follows: Lyophilized rabbit antiserum full protein $(100 \mathrm{mg})$ was dissolved in $2 \mathrm{ml}$ of glycine $/ \mathrm{HCl}$ buffer $(0.2$ molar, $\mathrm{pH} 2.8$; the buffer does not contain $\mathrm{NaCl}$ ). To the solution was added $50 \mathrm{mg}$ of active charcoal (Norit A) and the mixture was rotated for one hour $\left(20^{\circ} \mathrm{C}\right)$. The charcoal was removed by centrifugation $(10 \mathrm{~min}$ at $400 \times \mathrm{g})$ and the coal pellet

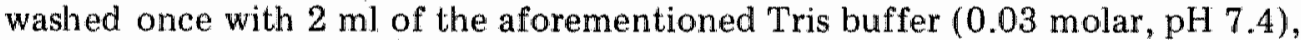
which was then added to the original solution. The combined solution was cleared by filtration (Millipore filter $0.2 \mu \mathrm{m}$ ) and the $\mathrm{pH}$ of the solution was adjusted to 7.4. The total solution was applied to and incubated on the sepharose-cortisol column for $2 \mathrm{~h}$ at ambient temperature. This incubation is necessary to attain maximum coupling of immunoglobulin to the solid phase. Apparently the amount of $\gamma$-globulin which is bound to the sepharose-cortisol from a solution of the former substance is dependent on the concentration of the applied solution. This might be expected to some extent on the basis of optimal circumstances for the coupling reaction between antibody and hapten viz. solid-phase-bound-hapten. If the concentration of the immunoglobulin in the solution is too low coupling can nevertheless be achieved by a longer reaction time. This can be obtained by pre-incubation, with careful stirring at ambient temperature, of the sepharose-cortisol in the immunoglobulin solution (in this case rabbit antiserum after charcoal treatment) for two hours (Table III). Next the total suspension was poured into a column $12 \mathrm{~cm} \times 0.9 \mathrm{~cm}$ and after complete sedimentation of the solid phase (about $30 \mathrm{~min}$ ) elution of the proteins from the column was started with the previously described Tris buffer. The immunoglobulin now remained on the column and was next eluted with glycine buffer as described before (Table I). 
ISOLATION OF CORTISOL-BINDING (ANTICSA) GLOBULIN BY AFFINITY CHROMATOCRAPWY ON SEPHAROSE-CORTISOL AFTER INCUBAIION WITH THE SOLID PHASE. ARSORBANGE (280 NM) OF ELUATES FROM SEPHAROSE-CORTISOL COLUMN $12 \mathrm{CM} \times 0.9 \mathrm{CM}$

1. from rabbit antiserum $(100 \mathrm{mg}$ dry protein).

II, from rabbit antiserum (100 mg diry protein) after treatment with charcosl. For both with Tris buffer. fraction volume $3 \mathrm{ml}$; after elutiom with $75 \mathrm{ml}$ of Tris buffer, elution with glycine buffer is started (frat tion volume $3 \mathrm{ml}$. A: clution with Tris buffer $0.03 \mathrm{M} ; \mathrm{PH} 7.4$ : elution with glycine/HCl buffer $0.2 \mathrm{M}$, $\mathrm{pH} 2.8$, containing $0.5 \mathrm{M} \mathrm{NaCl}$.

\begin{tabular}{|c|c|c|c|c|c|c|c|}
\hline \multicolumn{4}{|l|}{1} & \multicolumn{4}{|l|}{ II } \\
\hline $\begin{array}{l}\text { Fraction } \\
\text { No. }\end{array}$ & $A$ & $\begin{array}{l}\text { Fraction } \\
\text { No. }\end{array}$ & $\mathbf{B}$ & $\begin{array}{l}\text { Fraction } \\
\text { No. }\end{array}$ & $\mathbb{A}$ & $\begin{array}{l}\text { Fraction } \\
\text { No. }\end{array}$ & $B$ \\
\hline 1 & 1.690 & 26 & 0.110 & 1 & 1.150 & 26 & 0.145 \\
\hline 2 & 1.930 & 27 & 0.120 & 2 & 1.500 & 27 & 0.140 \\
\hline 3 & 1.665 & 28 & 3.200 & 3 & 1.470 & 28 & 0.255 \\
\hline 4 & 1.635 & 29 & 0.785 & 4 & 1.450 & 29 & 3600 \\
\hline 5 & 1.500 & 30 & 0.220 & 5 & 1.440 & 30 & 0.655 \\
\hline 6 & 1.530 & 31 & 0.125 & 6 & 1.420 & 31 & 0.225 \\
\hline 7 & 1.400 & 32 & 0.093 & 7 & 1.350 & 32 & 0.140 \\
\hline 8 & 1.340 & 33 & 0.078 & 8 & 1.350 & 33 & 0.100 \\
\hline 9 & 1. 340 & 34 & 0.069 & 9 & 1.300 & 34 & 0.086 \\
\hline $10^{* 4}$ & 1.340 & 35 & 0.031 & $10 *$ & 1.260 & 35 & 0.062 \\
\hline 11 & 1.300 & & & 11 & 1.110 & & \\
\hline 12 & 1.240 & 40 & 0.010 & 12 & 0.930 & 40 & 0.009 \\
\hline 13 & 0.615 & & & 13 & 0.650 & & \\
\hline 14 & 0.525 & & & 14 & 0.505 & & \\
\hline 15 & 0.405 & & & 15 & 0.390 & & \\
\hline 25 & 0.100 & & & 25 & 0.130 & & \\
\hline
\end{tabular}

* Starting from fraction no, 10 elution is done with buffer. Fractions $1-9$ are eluted while applying the sample to the column.

In fact the amount of immunoglobulin obtained by this procedure is not really larger than in the first experiment, when the antiserum was not pretreated with active charcoal to remove the endogenous cortisol. Our second hypothesis thus was not confirmed.

\section{Labeling of the cortisol-binding immunoglobulin with iodine-125}

To investigate the suitability of the isolated immunoglobulin for use in immunoradiometric assay of cortisol in blood serum, labeling of the former was performed with iodine-125. The method used was exactly as described elsewhere (chloroamine- $T$ method [4]). Of course the possibility had to be considered that during the labeling procedure the cortisol-binding properties of the protein might be lost. Purification of the labeled protein, however, was possible in exactly the same way by affinity chromatography over sepharose cortisol as we described for the isolation of the unlabeled immunoglobulin (Table IV). As the underlying principle of the purification procedure is the binding of immunoglobulin to cortisol, it is clearly demonstrated that the labeled protein still reacts with cortisol. The introduction of the iodine-125 into the $\gamma$-globulin molecule does not interfere with the immunological properties concerned. The importance of those findings is that the tracer for the 


\begin{tabular}{|c|c|}
\hline Fraction Wo. & Elution with Tris buffer, of 8.0 \\
\hline $1-4$ & Free fod fde-125 \\
\hline $5-10$ & Tallimis \\
\hline $11-18$ & Small pieats \\
\hline \multirow[t]{2}{*}{$19-23$} & Talling \\
\hline & $\begin{array}{l}\text { Elwion with glyethe/buffer, pH } 2.8 \\
\text { (disingegrations per second) }\end{array}$ \\
\hline 26 & 2148 \\
\hline 27 & 2038 \\
\hline 28 & 5928 \\
\hline 29 & 20000 \\
\hline 30 & 8290 \\
\hline 31 & 5600 \\
\hline 32 & 4400 \\
\hline 33 & 4000 \\
\hline
\end{tabular}

assay can be obtained in a very pure state which is necessary for reliable and sensitive analyses.

\section{Discussion}

The production of cortisol-binding immunoglobulin in rabbits requires a high-molecular-weight cortisol complex in which cortisol functions as the hapten. We used CSA as described before [1]. As might be expected the antiserum was directed both against BSA (the protein moiety of the antigen) and against the cortisol moiety of the CSA. It is possible to remove the BSAbinding antibodies by an absorption technique as we demonstrated before [2] . That the remaining antibody which is reactive towards CSA really enters into reaction with the cortisol moiety of CSA is proved by its isolation on sepharosecortisol as a solid phase in affinity chromatography.

The generally-found low titers of antisera directed and raised against nonprotein mammalian hormones can probably be explained by accepting the hypothesis that part of the raised immunoglobulin is saturated in vivo with endogenously produced hormones. We aid not succeed in removing these by active charcoal treatment of the antiserum. This might not be very surprising since the binding of the hormones (haptens) to the antibody is probably much stronger than to naturally occurring transport proteins (in this case endogenous cortisol-binding $\alpha$-globulin transcortin).

Isolation of specific antibodies can be realized by various forms of affinity chromatography. We found the most suitable method to be coupling of immunoglobulin to hapten-bound solid phase material. We found the same to be true for rabbit antiserum raised against a thyroxine-BSA complex where thyroxine is the hapten. Thyroxine-binding immunoglobulins could be isolated over a thyroxine-solid phase in affinity chromatography. Detailed characteriza- 
tion of the isolated cortisol-binding immunoglobulin (lgG) will be described in a later paper.

The affinity chromatography procedure appears to be dependent on the concentration of the antibody solution and the reaction time between the hapten moiety of the solid phase and the $\gamma$-globulin to be isolated. We think this is worth mentioning because similar problems may be encountered in many cases.

Comparable results can be obtained by applying the antibody solution to a solid phase filled column and starting the elution after a certain reaction time. This procedure in general is much more laborious than the one we described because the void volume of the column is often too small to contain the entire antibody solution, which then must be applied in fractions, each with a certain reaction time.

In order to investigate the possibility of using the purified antibody in immunoradiometric assay we labeled the isolated immunoglobulin with iodine125; the immunological properties remained unchanged to the extent investigated. Our purpose is to develop a highly sensitive assay for the determination of small amounts of cortisol in biological material. This should be possible by immuno-radiometric assay [5] better than by the normal procedure of radioimmunoassay where the tracer does not react in exactly the same way as the compound to be determined. Furthermore the competing reaction in itself puts a limit on the sensitivity of the analysis. It seems worth while to try to overcome these difficulties at least partly by using a labeled antibody, and this is being studied in our laboratory.

\section{References}

1 Brombacher, P.J., Gijzen, A.H.J., Janssens, H.H.P. and Soons, M.P.J. (1975) Clin. Chim. Actii 58,173 . 176

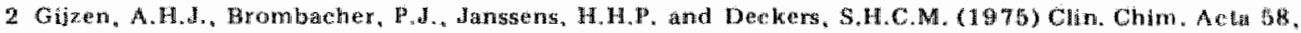
$177-180$

3 Heyns, W., van Baelen, H. and de Moor, P. (1967) Clin. Chim. Acta 18, $361-370$

4 Hunlet. R. (1970) Proc. Sod. Fxp. Biol. Med.133.989-4992

5 Wowdhead, M.S., Addisam, G.M. and Hales, C.N. (1974) 8r. Med. Bull. 30, 44-49 


\title{
DEVELOPMENT OF A HIGHLY SPECIFIC ANTISERUM AND INTRODUCTION OF CELLULOSE COUPLED IMMUNOGLOBULIN AS A SOLID PHASE FOR A DIRECT ASSAY OF CORTISOL IN HUMAN BLOOD SERUM
}

\author{
A.H.J. GIIJZEN
}

Isotopes Laboratory. De Wener-Ziekenhwis, Heerlen (L), (The Netherlands)

(Accepted October 22nd, 1976)

\section{Summary}

The synthesis and characterization of the immunogen cortisol-carboxymethoxim(bovine) serum albumin (COA) and the raising of an antiserum against it in rabbits is described. The harvested antiserum is characterized by immunodiffusion and immunoelectrophoresis techniques. Next the IgG immunoglobulins were separated from the serum by chromatography on DEAE cellulose, and the presence of specific cortisolbinding immunoglobulin is proved by isolation via affinity chromatography on sepharose-AH-cortisol.

Both the antiserum and the IgG-fraction were coupled to cellulose in order to synthesize solid phase binding agents to be used in the radioimmunoassay of cortisol. Affinity constants for the reaction of cortisol with several binding agents were determined and compared.

It was found that a simple and accurate direct analysis can be set up using IgGcellulose as a solid phase, where a low $\mathrm{pH}(3.5)$ of the reaction medium is chosen to prevent interference of sample serum protein, especially transcortin. The sensitivity of the assay system developed here was increased more than tenfold as compared to previously described procedures. Although maximal sensitivity is obtained with extracted steroids, the method described was developed for determination without extraction, still with excellent sensitivity.

\section{Introduction}

In previous papers $[1,2,3]$ we demonstrated the superiority of a radioimmunoassay system over a competitive protein binding method for the determination of cortisol in human plasma. The affinity of a cortisol binding $v$-globulin for cortisol and the increased specificity as compared to transcortin were clearly demonstrated. However, in the field of antibody-hapten reaction systems much depends on the affinity constant of 
the complex and on the selectivity of the available antibody. Therefore we thought it justified to raise a rabbit $\gamma$-globulin different from the one we used before.

In our earlier investigations, a cortisol-binding immunoglobulin was raised in rabbits by immunization with cortisol-21-succinyl-(bovine)-albumin (CSA) and subsequent isolation of the $y$-globulin by appropriate affinity chromatography. On account of side chain derivatization of cortisol in the immunogen synthesis the demonstrated selectivity pattern agrees with what might be expected, i.e. a certain nonspecificity toward the structural characteristics of the substituted steroid nucleus. In order to obtain a binding protein with different specificity we synthesized a completely different immunogen, i.e. cortisol-3-carboxymethoxim-(bovine)-albumin (COA) and raised an antiserum against it in rabbits. The first aim was to enhance the specificity for cortisol in the radioimmunoassay and possible reduce the interference of 11-desoxycortisol, as the formerly used antiserum could not distinguish between these two compounds. For clinical practice this does not seem to be very urgent. However, as far as antiserum specificity is concerned, the cross reactivity with 11-desoxycortisol is a major problem. An immunogen in which the side chain of the molecule is not involved in the coupling to albumin should lead to the raising of a $/ \mathrm{globulin}$ of a different specificity to cortisol as compared with the previously used antiserum. This appeared to be true.

Apart from the use in radioimmunoassay, characterization of the antiserum and its immunoglobulin is done by immunodiffusion and electrophoresis techniques.

In order to facilitate the separation of free from antibody-bound hapten " a so called solid phase procedure is developed. The antiserum is coupled to cellulose and the reaction product used as a binding agent. Experimental details are given in this paper. Finally, a highly selective procedure is wanted for the direct determination of cortisol in micro samples of plasma or serum, with comparison of affinity constants of several modes (e.g. soluble or as a solid phase complex, at varying $\mathrm{pH}$ values) of binding protein. It appears that the highest avidity is obtained with cellulose-antiserum solid phase at pH 7.4 with extraction of cortisol from the biological sample. As problems might be expected in direct analysis (without serum extraction) on account of sample protein interference, it was considered that performing the reaction at decreased $\mathrm{pH}$ might bypass this protein effect. As a binding agent cellulose-(antiserum IgG)-solid phase was used. This appears to be the most convenient method with high selectivity and specificity $\left(\mathrm{K}=6.3 \times 10^{8} M^{-1}\right)$.

\section{Synthesis and isolation of cortisol-3-carboxymethoxim-[bovine]-albumin}

Cortisol (3.4 mmol, $1232 \mathrm{mg}$ ) and carboxymethoxylamine hemichloride $(8.4 \mathrm{mmole}, 918 \mathrm{mg}$ ) are dissolved in $100 \mathrm{ml}$ of ethanol. The $\mathrm{pH}$ is adjusted to 9.9 by adding $18 \mathrm{ml}$ of $1.25 \mathrm{M} \mathrm{NaOH}$ in water solution. The mixture is boiled under reflux during 90 minutes whereupon the volume is decreased to $10 \mathrm{ml}$ by evaporating the solvent. Next $10 \mathrm{ml}$ of $\mathrm{H}_{2} \mathrm{O}$ is added and the solution is extracted 3 times with $25 \mathrm{ml}$ portions of diethylether to remove uncoupled cortisol. The formed oxim is then precipitated by adding dropwise concentrated hydrochloric acid to $\mathrm{pH} 6.5$; a slurry is formed and is centrifuged. The $\mathrm{pH}$ of the supernatant is adjusted to 8.0 and against to 6.5 with $\mathrm{HCl}$, when more precipate is formed and isolated by centrifugation. This is repeated three times. To the combined precipitate is added $10 \mathrm{ml}$ tetrahydrofuran (THF) and the clear solution is evaporated with rotating in vacuo to $1-2 \mathrm{ml}$. The volume is brought to $10 \mathrm{ml}$ with water and extracted thrice with ether. The combined ether is dried over night on sodium sulphate, filtered and the sodium sulphate washed with dry ether, whereupon the solution is evaporated till dryness. The yield of the synthesis is $900 \mathrm{mg}$ of cortisol-3- 
carboxymethoxim, melting range $95-104^{\circ} \mathrm{C}$. The substance is stable at room temperature in dry atmosphere.

Thin layer chromatography of the reaction mixture of cortisol and carboxymethoxylamine demonstrates the gradual development of the oxim formation, which appears to be maximal after 90 min reaction. The yield of the synthesis does not increase on prolonged reaction time. A small residual amount of cortisol in the chromatogram must be due to decomposition of the oxim during chromatography; the same appears to be true on chromatography of other cortisol-deriwates.

The UV adsorption maximum of the oxim is at $247 \mathrm{~nm}$ compared to $252 \mathrm{~nm}$ for cortisol. A similar shift is often observed [4]. Determination of the nitrogen content of the oxim (Kjeldahl analysis) gives a $\mathrm{N}$-content of $3.8 \%$ (calculated $3.2 \%$ ). The slightly elevated figure might be due to partial dioximformation; similar observations are reported by others [5]. For coupling to bovine albumin (BSA) 1 mmole (435 mg) of the oxim is dissolved in $10 \mathrm{ml}$ of THF and 1 mmole of tri-n.butylamine $(0.24 \mathrm{ml})$ is added, the mixture chilled to $4^{\circ} \mathrm{C}$ and then with cooling 1 mmole $(0.12 \mathrm{ml})$ of isobutylchloroformate is added dropwise and the reaction is allowed to proceed during $20 \mathrm{~min}$. In the meanwhile a solution of $1.38 \mathrm{~g} \mathrm{BSA}$ in $44 \mathrm{ml}$ of water is brought to $\mathrm{pH} 11.2$ by adding $1.1 \mathrm{ml}$ of $1 \mathrm{M} \mathrm{NaOH}$; next $45 \mathrm{ml}$ of THF is added and the pH readjusted at 11.2. After cooling in a melting ice bath the above mentioned reaction mixture is added dropwise with stirring and the mixed anhydride is coupled to the BSA; the wolle reaction proceeds at $0^{\circ} \mathrm{C}$ during $3 \mathrm{~h}$ with gas evolution and the $\mathrm{pH}$ drops to 8.0 which indicates the completement of coupling. A first isolation of the protein fraction is performed by gel filtration on Sephadex G25-medium (Pharmacia column K 50/60). The protein is isoelectrically precipitated from the eluate at $\mathrm{pH} 4.5$ during $16 \mathrm{~h}$ at $4{ }^{\circ} \mathrm{C}$. The precipitate after centrifugation is redissolved in $35 \mathrm{ml}$ of water and again subjected to gel filtration (sephadex G 100, column K 50/60); elution with water (Fig. 1).

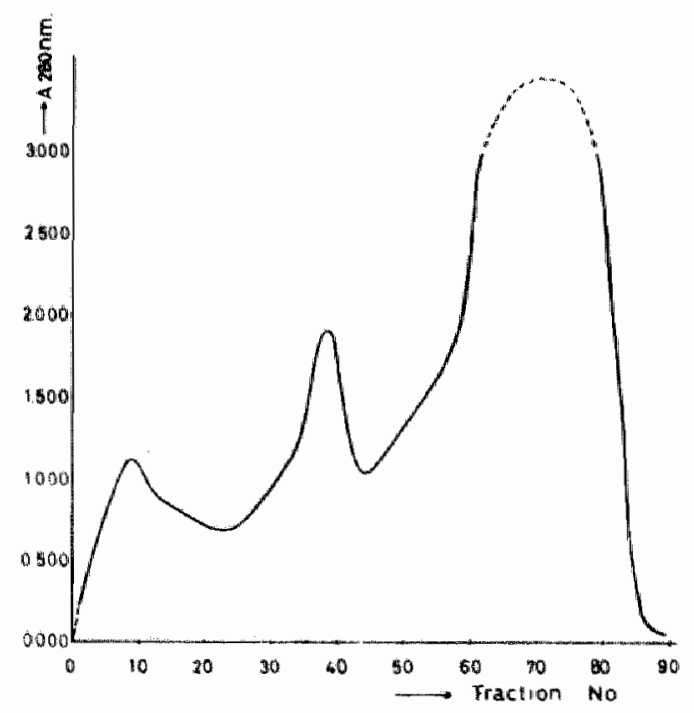

Fig. 1. Gel filtration elution curve for isolation of COA. Sephadex G 100; elution with water; fraction volume $8.5 \mathrm{ml}$. Fractions $50-84$ give a strongly positive reaction with tetrazolium blue indicating the presence of cortisol-groups in the protein conjugate. 
Analysis of the immunogen (Kjeldahl-analysis) gives $13.3 \% \mathrm{~N}$-content; BSA gives. a $\mathrm{N}$-content of $16.0 \%$. Calculation shows that 44.1 mole cortisol are bound per mol of BSA via the carboxymethoxim linkage. This is a clear advantage over cortisol-21succinylalbumine containing 28 moles of cortisol linked to one mole of BSA. This is in accordance with published data [6] on the antigenicity of steroid-protein complexes, stating that the molar ratio steroid vs. protein must be over 20 , and preferably much higher. The use of this immunogen can be expected to result in antisera with higher titres than those harvested from rabbits treated with the CSA formerly.

After substraction of the UV-absorption spectrum of BSA from the COA-spectrum the difference curve showed a well defined maximum at $246 \mathrm{~nm}$ indicating the presence of cortisol-groups [7] in the molecule (Fig. 2). An attempt to confirm the cortisol content of the antigen as calculated from the $\mathrm{N}$-analysis data was not succesful. As in former experiments [7] the number calculated from the spectra (i.e. 26 groups cortisoloxim/mol albumin) is much lower than determined from the $\mathrm{N}$-content. This is probably due to the fact that the molar extinction coefficient of the cortisol-oxim-albumin molecule is much lower than would result from additive calculation starting with the molar extinctions of albumin and cortisol carboxymethoxim. This supposition is supported by the ratio of the number of cortisol groups calculated from the spectral data to the number of groups present (as determined from the $\mathrm{N}$-analysis). Both for CSA and for COA we found 0.64 .

Furthermore an intensive blue color is developed on reaction of COA in an alkaline tetrazolium blue solution also indicating reactive cortisol groups in the immunogen.

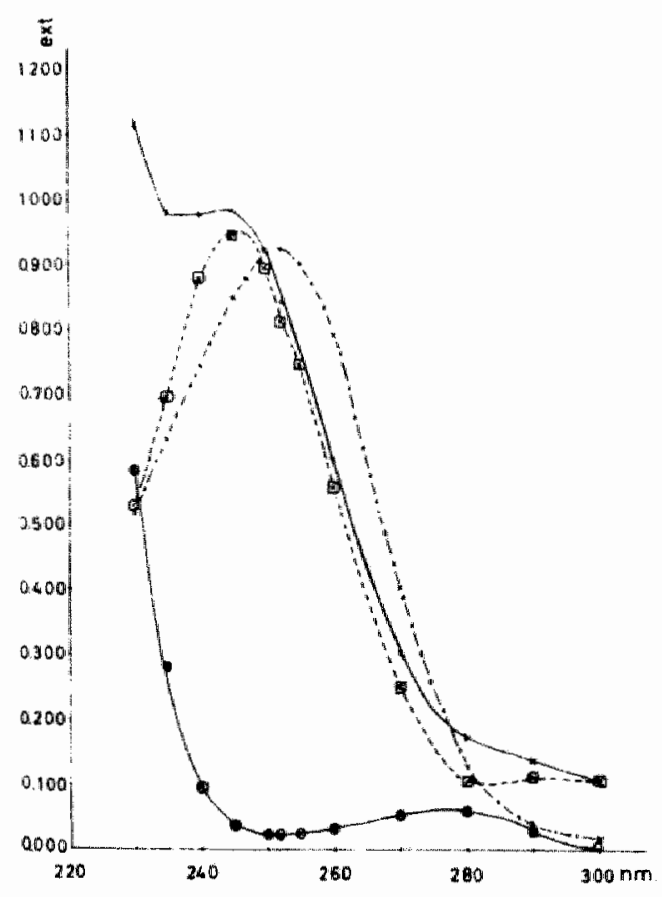

Fig. 2. Ultraviolet absorption curves of solutions of $1.95 \times 10^{-6} \mathrm{MCOA}\left(\times-{ }_{-} \times\right)$;

$1.95 \times 10^{-6} M$ BSA $\left({ }^{-6}{ }^{\circ}\right) ; 48.04 \times 10^{-6} M$ cortisol-3-0-carboxymethoxim $(\times \ldots . . \times)$. The difference curve ( a defenite maximum at $246 \mathrm{~nm}$ (see text). 
Four rabbits were immunized with the synthesized immunogen by giving once multiple intracutaneous injections of small amounts ( 20 dosis from $0.5 \mathrm{ml}$ ) of a mixture of $0.5 \mathrm{ml}$ complete Freunds adjuvans and $0.5 \mathrm{ml}$ of a solution of $0.5 \mathrm{mg} C O A$ in isotonic saline. At the same time an intramuscular injection of $0.5 \mathrm{ml}$ of the mixture is given. The i.m. adminstration is repeated once weekly in the next four weeks; a pause of one month is taken and after that period a booster injection of $0.5 \mathrm{mg}$ of COA in $0.5 \mathrm{ml}$ incomplete Freunds adjuvans is given. Booster injections are repeated once monthly.

Titration of antiserum is performed four weeks after the beginning of immunization and one week after every booster injection. Titres increased from 1:500 up to $1: 11000$ in three months as determined by the appropriate experimental set up: binding of $50 \%$ of $0.18 \mathrm{pmole}$ tritiated cortisol (specific activity $40 \mathrm{Ci} / \mathrm{mmole}$ ) by $0.1 \mathrm{ml}$ diluted antiserum in a total volume of $1 \mathrm{ml}$. This is much better than the antiserum titre after immunization of rabbits with CSA, where we obtained a maximum titre of 1:2500 after four months. The high titre of the anti-COA serum obtained confirms our earlier supposition about the antigenicity of $\mathrm{COA}$, based on its relatively high cortisol content.

Immunodiffusion experiments (Ouchterlony-technique) with the new antiserum revealed clearly distinguished immunoprecipitation with BSA and COA (heavy precipitation) and also against CSA. This is firm proof for the presence of different immunoproteins in the serum against the albumin and against the cortisol-moiety either present in COA and CSA (Fig. 3). The presence of the latter reaction demonstrates that the immunization of rabbits with COA raises antiserum, especially directed against the cortisol in the immunogen even to the extent that there is affinity towards the cortisol moiety in the structurally essentially different immunogen CSA.

The stronger reaction with COA suggests that antibody reactivity is to a considerable extent directed towards the used antigen. This might lead to the suggestion that the sensitivity of the analysis, using this antiserum, could be increased by oxim formation of the cortisol to be analyzed prior to the radioimmunoassay, on account of greater similarity of cortisol-3-oxim with the used antigen. A drawback of such a procedure, however, would be that the cortisol to be determined must be extracted from the biological sample since oxim formation in full plasma is not possible.

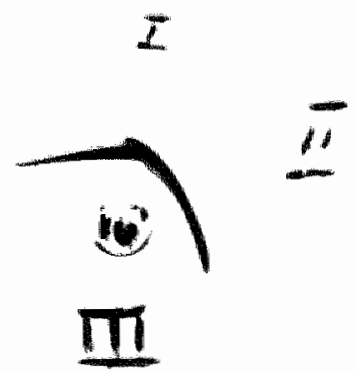

Ouchterlony-immuno-precip.

I BSA

II Cortisol-3-oxim-BSA (COA)

III Cortisol-21-succinyl-BSA (CSA)

IV (center well) anti-COA-serum

Fig. 3. Immunoprecipitation of anti-COA serum. 
In order to purify, isolate and characterize the cortisol-binding inmunoglobulin raised against COA, affinity chromatography is performed using several procedures, i.e. over cortisol-3-carboxymethoxim-AH-sepharose viz. over cortisol-21-succinyl-AHsepharose. The sepharose derivates were synthesized as described in an earlier paper [3] for the latter compound and with a similar procedure for the first one.

In the paper mentioned above we showed the persisting presence of albumin in the $v$-globulin fraction even after elaborate purification. In order to bypass this phenomenon we first separated the total IgG fraction from the rabbit serum by chromatography over DEAE-cellulose: $60 \mathrm{mg}$ of dried antiserum protein dissolved in $1 \mathrm{ml}$ of $0.10 \mathrm{M}$ phosphate buffer $\mathrm{pH} 7.0$ is applied on a column $(30 \mathrm{~cm} \times 2.5 \mathrm{~cm})$ containing DEAE-Sephadex A 50 swollen in the same buffer. Chromatography is performed by gradient ellution, starting with 0.1 molar phosphate buffer $\mathrm{pH} 7.0$ and gradually mixing with the same buffer containing 0.5 molar $\mathrm{NaCl}$. The IgG fraction eluate is lyophylized and the protein

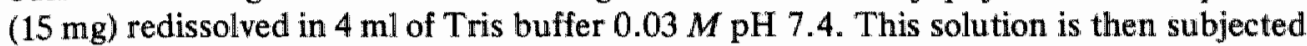
to affinity chromatography over either one of the above mentioned sepharose derivatives. Both sepharose-cortisol derivates were suitable for this purification procedure. The protein solution is added to $9 \mathrm{ml}$ of a slurry of solid phase (cortisol-sepharose derivate, $1 \mathrm{~g}$ in $4 \mathrm{ml}$ Tris buffer) and mixed with stirring at $20^{\circ} \mathrm{C}$ during $1.5 \mathrm{~h}$ and finally at $37^{\circ} \mathrm{C}$ during $15 \mathrm{~min}$ in order to complete coupling of the specific immunoglobulin to the solid phase. Next the mixture is filled into a column $(12 \mathrm{~cm} \times 0.9 \mathrm{~cm})$ and after settling elution is started with Tris buffer to remove uncoupled protein. This being completed, the column is eluted with a $0.2 \mathrm{M}$ glycine- $\mathrm{HCl}$ buffer $\mathrm{pH} 2.8$ to break the antibody-solid phase complex. The immunoglobulin is eluted in a very sharp fraction (Fig. 4).

A yield of about $20 \%$ of the total $\gamma$-globulin content of the serum raised against COA or about $4 \%$ when the serum was raised against CSA. Antibodies against BSA are virtually absent as demonstrated by the Ouchterlony techniques. Moreover in this purified IgG preparation no albumin is present in contrast to a former procedure [3]. The prepurification step over DEAE cellulose has proven to be effective and necessary. The immunoglobulin solution is lyophylized and the dried substance kept at $4^{\circ} \mathrm{C}$.

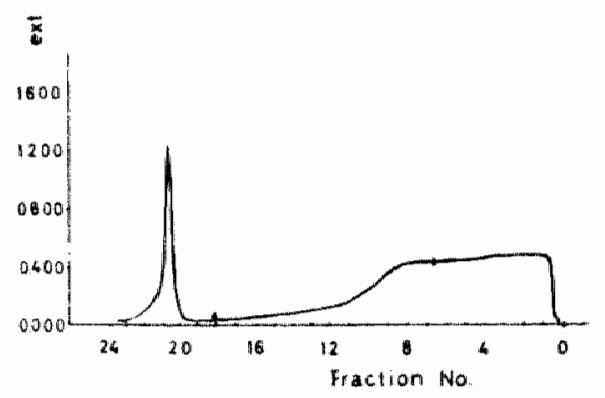

Fig. 4. Affinity chromatography of anti-COA immunoglobulin IgG. Support: cortisol-3-oxim-AHsepharose. Fractionvolume: $4 \mathrm{ml}$. Elution of specific $\mathrm{lgG}$ in fractions 20 and 21 as detected by continuous monitoring at $280 \mathrm{~nm}$ (see text). 
The separation of free from antibody-bound tracer is one of the major problems in radioimmunoassay. Recently the use of so called solid-phase systems was introduced $[8,9]$ with the advantage that the antibody as such can easily be removed from the reaction medium. The coupling procedure is a modification of a method published elsewhere [9].

$\operatorname{BrCN}(3 \mathrm{~g})$ is dissolved in $2 \mathrm{ml}$ of dimethylformamide and water added ad $15 \mathrm{ml}$; with stirring $3 \mathrm{~g}$ of microcristalline cellulose (Sigmacell $20 \mu \mathrm{m}$ ) is added to the turbid solution immediately followed by $1 \mathrm{M} \mathrm{NaOH}$ (dropwise) until $\mathrm{pH} 10-11$. The $\mathrm{pH}$ is kept in this range by adding $\mathrm{NaOH}$ and the reaction is terminated in $15 \mathrm{~min}$. A total wolume of about $130 \mathrm{ml}$ of $\mathrm{NaOH}$ is needed. The reaction mixture is now filltered over a glass filter and the residu first washed with $250 \mathrm{ml}$ of water at $4^{\circ} \mathrm{C}$, next with 3 portions of $50 \mathrm{ml}$ each of aceton. The activated cellulose- $\mathrm{CNBr}$ is dried on the air and kept in a closed vessel at $4^{\circ} \mathrm{C}$.

A solution of $40 \mathrm{mg}$ dry substance of lyophylized rabbit antiserum in $4 \mathrm{ml}$ of borate buffer $(0.1 \mathrm{M}, \mathrm{pH} 8.5)$ is prepared and $800 \mathrm{mg}$ of activated cellulose- $\mathrm{CNBr}$ is added. The coupling reaction of protein with cellulose proceeds with stirring during $72 \mathrm{~h}$ at $4^{\circ} \mathrm{C}$. The suspension is then centrifuged and the precipitate washed 3 times with $50 \mathrm{ml}$ portions of the borate buffer. In order to inactivate any $-\mathrm{CNBr}$ groups left in the product the precipitate is suspended in $50 \mathrm{ml}$ of ethanolamine buffer solution $(1.0 \mathrm{M}, \mathrm{pH} 8.0)$ and stirred at ambient temperature during $60 \mathrm{~min}$.

After centrifugation the precipitate is treated twice during 20 min with $50 \mathrm{ml}$ portions of sodium acetate buffer $(0.1 \mathrm{M}, \mathrm{pH} 4.0)$ in order to remove non covalently bound protein. Final washing is performed three times with $50 \mathrm{ml}$ portions of a buffer $0.01 \mathrm{M}$ in sodium phosphate and $0.02 \mathrm{M}$ in citric acid, $\mathrm{pH} 3.5$ (P.C.-buffer used in the assay; vide infra). The prepared antiserum-cellulose solid phase (solid phase I) is kept suspended in the assay buffer (P.C.-buffer) at $4^{\circ} \mathrm{C}$.

The above described solid phase consists of several proteins from the antiserum coupled to cellulose. The same procedure for coupling is applied to the isolated IgG fraction (as described before) of the antiserum departing from $30 \mathrm{mg}$ of lyophylized IgG and $600 \mathrm{mg}$ of activated cellulose-CNBr. This yields a solid phase consisting of cellulosecoupled IgG (solid phase II) without the presence of other rabbit serum proteins.

Determination and comparison of affinity constants of cortisol-binding immunoglobulins; influence of the state of binding protein [dissolved; solid phase], the $\mathrm{pH}$ and the determination of cortisol with and without extraction from the serum sample

\section{Materials}

Steroid-free human blood serum is prepared by charcoal treatment and standard amounts of cortisol are dissolved in this serum. A series of solutions prepared containing viz. $8,4,3,2,1,0.5$ and $0.25 \mu M$. The tracer solution in phosphare-citrate buffer contains $\left[1,2 \cdot{ }^{3} \mathrm{H}\right]$ cortisol, specific activity $40 \mathrm{Ci} /$ mmole, $^{1.8} \times 10^{-3} \mu M$.

The antiserum is diluted with phosphate-citrate buffer (P.C.-buffer, vide infra), or the solid phase suspended in this buffer, to such a degree that on titration with tracer under the described experimental conditions $50 \%$ of the activity is bound.

The cortisol standards are used as such (solution in charcoal treated serum) or the cortisol is extracted by dichloromethane. The same applies to the unknown serum 
samples. The phosphare-citrate buffer (P.C.-buffer) is prepared by dissolving $1618 \mathrm{mg}$ of $\mathrm{Na}_{2} \mathrm{HPO}_{4} .2 \mathrm{H}_{2} \mathrm{O}$ and $4394 \mathrm{mg}$ of citric acid, adjusting the $\mathrm{pH}$ to 3.5 and adding water to a final volume of $1000 \mathrm{ml}$. The solution is about $0.01 \mathrm{M}$ in phosphate and about $0.02 M$ in citric acid.

\section{Assay procedure}

In a centrifuge tube is brought consecutively an adequate amount $(0.1-0.5 \mathrm{ml})$ of antiserum solution viz. solid phase suspension, 5al of cortisol standard or unknown sample, $0.1 \mathrm{ml}$ of tracer solution and P.C. buffer ad $1.0 \mathrm{ml}$. After incubation with rotating during $90 \mathrm{~min}$ at ambient temperature, free and bound fractions are separated; when soluble antiserum is used a common dextran $\mathrm{T}_{70}$-charcoal procedure was applied, which is of course not necessary in the solid phase assay. The tubes are centrifuged and the activity of an aliquot amount of the supernatant of standards and unknowns measured and the cortisol content of unknowns can be calculated in the usual way.

If the standards and serum are extracted, an aliquot of the extract is first evaporated to dryness in the centrifuge tube and the assay performed as described. From the amounts of unbound tracer $(F)$ and bound tracer $(B)$ the ratio $B / F$ is easily calculated. Plotting $B / F$ (ordinate) vs. $B$ (abcissa) gives a linear curve the slope of which is $-K$, where $K$ is the affinity constant of the reaction. Using antisera it now appears that with elevated amounts of cortisol (e.g. high concentration standards) the overall graphical representation of $B / F$ vs. $B$ shows a non-linear relation. This means that the antiserum is not homogenous or that aspecific binding of steroid to protein occurs. The graphical representation can be composed of two linear curves each connected with a different affinity constant. The same experiments were carried out with 11-desoxycortisol in order to determine the avidity of the binding proteins for this steroid. The data obtained are apparent affinity constants giving information on the possible interference of 11-desoxycortisol in the cortisol determination where labeled cortisol is used as a tracer. Another variation in the procedure is the use of a buffer of $\mathrm{pH} 7.4$ of equal ionic strength. As a matter of fact we started our series of experiments with this buffer which is commonly used in radioimmunoassay. It turned out, however, that at $\mathrm{pH} 7.4$, no avidity of solid phase coupled binding protein towards cortisol could be detected when the latter compound was added in serum. With extracted steroids, i.e. in a protein-free assay medium, cortisol was captured quite well. Those data suggested that perhaps the serum proteins in the sample (amongst them transcortin) inhibit binding of cortisol by the solid phase which could then be influenced by changing the $\mathrm{pH}$. This supposition was found to be true (see discussion), The results of the experiment are given in Table I.

\section{Table I}

Affinity constants $\mathrm{K} \times 10^{8} \mathrm{M}^{-11}$ of cortisol binding reactions

\begin{tabular}{|c|c|c|c|}
\hline \multirow[t]{2}{*}{ Binding Agent } & \multicolumn{2}{|c|}{$\mathbb{K} \times 10^{8} M^{-1}$} & \multirow{2}{*}{$\begin{array}{l}\text { Assay with or withou } \\
\text { extraction of steroid } \\
\text { from the sample }\end{array}$} \\
\hline & pH 7.4 & $\mathrm{pH} 3.5$ & \\
\hline transcortin solution & 0.31 & - & with extraction \\
\hline anti-CSA serum solution & 0.68 & - & with extraction \\
\hline anti-COA serum solution & 2.70 & 2.40 & with extraction \\
\hline anti-COA serum solid phase I & 13.00 & 5.40 & with extraction \\
\hline anti-COA serum solid phase I & 0 & 3.24 & without extraction \\
\hline anti-COA IgG solid phase II & 0 & 6.30 & without extraction \\
\hline
\end{tabular}




\section{Discussion and conchusions}

The described investigation was started to improwe the selectivity (specificity) of the immunoassay of cortisol especially with regard to the influence of 11 -desoxycortisol which interfered 100\% in existing methods, i.e. with transcortin and with anti-CSA serum as binding agents. An antiserum raised against cortisol-3-carboxymethoximbovine albumine (COA) could be expected to possess altered specificity. This supposition was confirmed, as can be seen from the affinity constants of solid phase II, i.e. $\mathrm{K}=$ $6.30 \times 10^{8} \mathrm{M}^{1}$ for cortisol and $\mathrm{K}=2.66 \times 10^{8} \mathrm{M}^{-1}$ for 11 -desoxycortisol (Fig. 5 ).

The inherent purpose of the study was to see whether by obtaining a more selective (specific) binding agent the sensivity of the method could be raised. From the results reported in Table I it can be deduced that this aim too is reached. As, under the conditions of the experiment ( $50 \%$ tracer binding with no added cold hapten), the theoretical sensitivity of the assay system is about the reciprocal value of the affinity constant [10], the values in Table II can be compared. The solid phase II system appears to be 20 times as sensitive as the transcortin system and 10 times as the anti-CSA system. Hence the size of the serum sample needed for the determination could be reduced from $0.1 \mathrm{ml}$ to $5 \mu 1$.

A general purpose of any study on determination methods is of course to investigate the possibility of simplifying the assay procedure for use. As major problems in steroid radioimmunoassay are the separation of bound from free hapten and the preference for a direct assay in the serum sample the introduction of solid phase antibody systems in actually studied with great interest. We succeeded indeed in coupling the raised antiserum to several solid supports (sepharose, cellulose, Corning glass) and obtained best results with cellulose. It must be supposed that only a minor part of the solid phase antiserum is to be considered as active binding agent, since many of the protein present in the antiserum do not participate in the hapten-antibody reactions. This does not, however, mean that the said proteins as a solid phase would not interfere with the hapten-antibody reaction, e.g. by steric hindrance or by masking active sites on the solid phase surface. It is also possible that non-specific binding of hapten to immunologically inactive proteins occurs; this is more likely when the concentration of aspecific protein is relatively high as in solid phase systems compared to simply diluted serum. Indeed a good affinity constant for the hapten antiserum reaction at $\mathrm{pH} 7.4$ was found with solid phase 1 , indicating to a high degree cortisol capture from a reaction medium free of dissolved protein.

When a serum sample containing cortisol was added as such, however, no cortisol was captured at all. This must be due to steric hindrance and aspecific masking of binding sites by the added sample serum proteins in solution. To reduce these interprotein effects several ways are open, e.g. to remove all proteins (steroid extraction) or to destroy the serum proteins by preheating the serum. A possibility to overcome the

\section{Table 11}

\section{Sensittivity of cortisol ria-assay proced ures with different binding agents}

\begin{tabular}{ll}
\hline Binding agent & Sensitivity $\mu M$ \\
\hline transcortin & $3.2 \times 10^{-2}$ \\
anti-CSA serum pH 7.4 & $1.5 \times 10^{-2}$ \\
anti-COA serum solid phase 1, pH 3.5 & $0.3 \times 10^{-2}$ \\
anti-COA IgG solid phase II. $\mathrm{pH} 3.5$ & $0.16 \times 10^{-2}$ \\
\hline
\end{tabular}


coupling of serum proteins to the solid phase antiserim and to prevent transcortin binding interference, is to create such reaction circumstances that those interactions are rather unlikely; this can be achieved by lowering $[11,12]$ the $\mathrm{pH}$ of the solution to 3.5 . An unwanted side effect, however, was the decrease of affinity of cortisol for the binding agent; it was considered that the latter could be enhanced by not using total antiserum solid phase but to use a purified modification, i.e. the IgG fraction of the antiserum which must be expected to be rich in cortisol-binding immunoglobulin. This hypothesis appeared to be quite true and the solid phase II (anti-COA)-IgG-cellulose was chosen as the most favourable binding agent. The conclusions to be drawn from the described investigation thus can be in the first place that we succeeded in obtaining an antibody with higher affinity for cortisol than for 11-desoxycortisol.

In Fig. 5 the Scatchard-plots are given for the binding of cortisol and 11-desoxycortisol to the IgG and the affinity constant for cortisol is calculated. It must be pointed out here, that only "apparent" affinity constants for 11-desoxycortisol can be calculated from these plots. It should be kept in mind that in all experiment tritiated cortisol was used as a tracer. The 11-desoxycortisol is bound as far as competition with the cortisoltracer occurs. This of course is exactly what we want to know: the interference of 11-desoxycortisol in this cortisol assay system. Consequently it is not possible to determine the "real" affinity constant for the reaction of the IgG and 11-desoxycortisol in this way; this requires the use of labeled 11-desoxycortisol, to which we were not disposed at the time of the investigation. Furthermore a firm conclusion from the described experiments regarding binding capacity of 11-desoxycortisol and the prevalence of specific binding sites for this steroid, is difficult.

A second conclusion is that the sensitivity of the cortisol determination was improved more than tenfold.

Finally the simplicity of the cortisol determination was greatly increased by using the cellulose-IgG solid phase system, where it is possible to bypass a steroid extraction

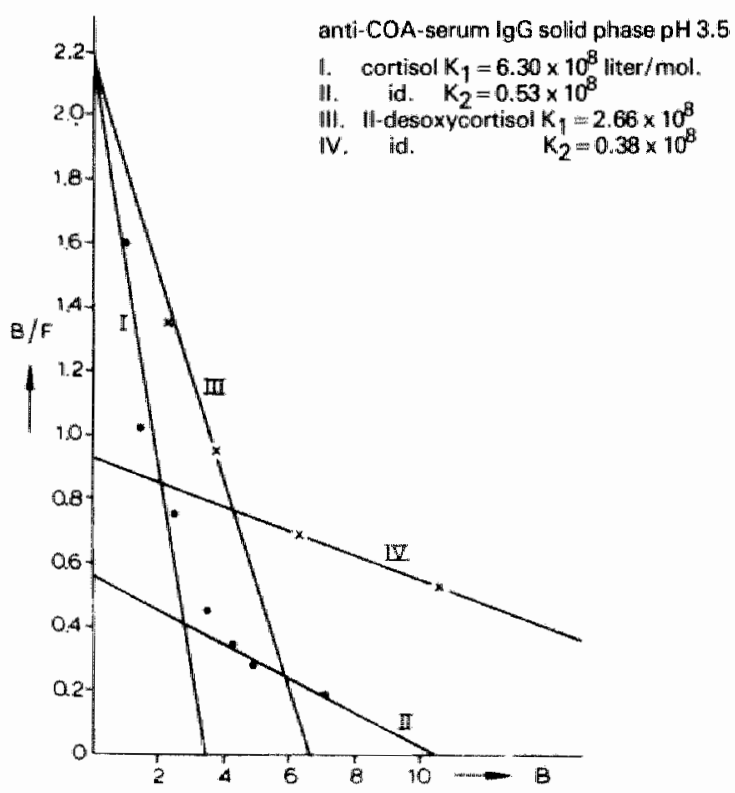

Fig. 5. Scatchard plots for solid phase II (see text). 
step. The developed procedure is highly selective, sensitive and accurate and can easily be performed in routine laboratories; normal values at $9.00 \mathrm{a} . \mathrm{m}$. , range $0.23-0.73 \mu \mathrm{M}$, variation coefficient $8.0 \%$, sensitivity determined as lowest concentration differing significantly from zero is $0.05 \mu \mathrm{M}$.

\section{Acknowledgement}

The author wishes to express his sincere thanks to Dr. P.J. Brombacher, Mr. H.H.P. Janssens and Miss S.H.C.M. Deckers for stimulating discussions and valuable technical assistance.

\section{References:}

1 P.J. Brombacher, A.H.J. Gijzen, H.H.P. Janssens and M.P.J. Soons, Clin. Chim. Acta, 58 (1975) 173-176.

2 A.H.J. Gijzen, P.J. Brombacher, H.H.P. Janssens and S.H.C.M. Deckers, Clin. Chim. Acta, 58 (1975) 177.180.

3 A.H.J. Gijzen, Clin. Chim. Acta, 66 (1976) 77-84.

4 S. Lieberman, B.F. Erlanger, S.M. Beiser and F.G. Agathe Jr., Rec. Progr. Horm. Res, 15 (1959) 165-200.

5. H. Vetter and W. Vetter. J. Steroid Bioch., 5 (1974) 197-202.

6 G.D. Niswender and A. Rees Midgley, in: F.G. Peron and B.V. Caldwell (Eds.). Immunologic methods in steroid determination, Plemum Press, N.Y. 1970, p. 149-166.

7 P.J. Brombacher, Stimulatie van de bijnierschors met 18-ACTH, Thesis, Amsterdam, 1975, p. $25-30$.

8 L.. Wide, Acta Endocrinol. (Copenhagen), Suppl. 142 (1969), $207-218$.

9 J. Seth, F.J. Rutherford and L. McKenzie, Solid phase RIA of thyroxine in untreated serum, Clin. Chem., 21 (1975) 1406-1413.

10 R.S. Yalow and S.A. Berson, General aspects of radioimmunoassay procedures: in vitro procedures with radioisotopes in medicine, IAEA, Vierna 1970 , pp. 455-479'

11 S.L. Morrison and M.E. Koshland, Proc. Nat. Acad. Sci. U.S.A., 69 (1972) 124-128.

12 H. Bennich and S.G.O. Johannson, Adw. Immunol., 13 (1971) 1-55. 


\section{SPECIFICITY AND SENSITIVY OF BINDING PROTEINS IN THE RADIO-IMMUNO-ASSAY OF CORTISOL. A COMPARATIVE STUDY WITH SEVERAL PROTEIN BINDING
AGENTS IN REACTIONS WITH MANY STEROIDS}

\section{A.H.J GIIZEN}

Isotopes Laboratory, De Wever-Ziekemhuis, Heerlen (L). (The Netherlands)

(Accepted October 22nd, 1976)

\section{Summary}

A comparison concerning avidity towards cortisol and 10 other steroids was made between several binding proteins either in solution or bound to cellulose as so called "solid phase" reagent.

Human blood cortisol binding protein (CBP, transcortin), and two distinctly different cortisol-binding rabbit antisera and the isolated immunoglobulins thereof were compared in their avidity to bind cortisol and several other steroids.

The antisera were harvested from rabbits immunized with either cortisol-21succinyl-albumin (CSA) or cortisol-3-oxim-albumin (COA). The latter antiserum, having the highest titre in cortisol titration, showed the greatest specificity and was most useful as a binding reagent in cortisol radioimmunoassay when used as a solid phase reagent. The determination of cortisol in micro samples of blood serum is possible without steroid extraction or serum protein denaturation and with only minor influence of steroid impurities in the sample to be analyzed. Affinity constants for all compared binding reagents and steroids are given.

\section{Introduction}

The surtability of a binding protein in competitive protein binding reactions or in radioimmunoassay is generally estimated by titrations with the compound to be bound. This means that the appropriate dilution of the protein solution is determined for use in the assay to be performed. As a rule the protein solution is either a mammalian blood serum containing more or less specific binding proteins for the considered substance, or more often an animal antiserum raised against it. If the compound to be determined is a small molecule or lacks antigenic activity, it can be coupled as a hapten to a larger immunogenic molecule, e.g. bovine serum albumin (BSA). In previous publications $[1-4]$ we described the production of two distinctly different cortisol binding antisera. 
The properties of the immunoglobulins induced are to a great extent dependent on the structure of the used antigen and can thus be influenced. In general the binding sites or antigenic determinants on the raised immunoglobulin have preference for that part of the hapten molecule which is distant from the conjugation place to the protein part of the immunogen. When the conjugation occurs in position 21 , it can be expected that the specificity of the raised antibody will mainly be directed towards the A-ring. On the other hand, a conjugation at the 3-position will yield an antibody with specificity for the side chain as well as for all groups far from the conjugation place including the 11-oxy group. This however does not mean that groups or structural characteristics of the molecule adjacent to the conjugation should have no influence on the specificity of the antibody.

Another important factor next to the said titre or "antibody concentration" however is the degree to which the analysis is influenced or disturbed by compounds in the sample which are not to be determined. The selectivity, or specificity, of an antibody for a special hapten is designated as high if the accuracy of the analysis is pertained, even in samples containing relatively elevated concentrations of the substances structurally related to the one to be measured. If no influence at all can be demonstrated the reaction is stricto sensu "specific".

In a chosen analysis system the dilution of the antiserum solution and the amount of added tracer are of course important for the sensitivity of the reaction. A high binding protein concentration might lead to more aspecific binding reactions, which means that the selectivity of the reaction is diminished. A high concentration of tracer will lead to diminished sensitivity of the reaction system. For a certain constitution of the reaction medium the influence of other steroids on the cortisol determination can be measured and expressed as percentage interference $[1,5]$.

When the properties of binding proteins are compared amongst each other, a far better parameter is the calculation of the affinity constant for the reaction between steroid and binding protein; this only depends on the factors governing the law of mass action and is concentration-independent. The affinity constant is calculated by plotting the equation $B / F=K . B .+$ n.K.A $b_{t}$ where: $\mathbf{B}$, concentration of bound hapten; F, Concentration of unbound (free) hapten; $\mathbb{K}_{\text {, }}$ affinity constant; $\mathbf{n}$, number of binding sites per mol of protein; $A b_{1}$, total binding (antibody) concentration, in a so called Scatchard plot [6,7]. A lineair relationship exists between $B / F$ (ordinate) and $B$ (abscissa) giving $-K$ as the slope of the line.

When the concentration of binding protein is known exactly, it is also possible to calculate the number of active binding sites per mole; where in general the $A b_{b}$ is not exactly known (antibody impurity or just in diluted antiserum) the total number of binding sites $\mathrm{n} . \mathrm{A} \mathrm{b}_{\mathrm{t}}$ can be measured.

In this paper several binding proteins are compared on the dilution independent basis of the affinity constants for the reaction of any protein with cortisol and a number of steroids. Conclusion can then be drawn regarding both specificity and sensitivity for the cortisol determination. In a common reaction set up, the concentration of the tracer is kept as low as possible in order to make the competition between tracer and hapten possible, also for small amounts of the latter. It can be calculated that at a total "binding site" concentration and tracer concentration leading to $50 \%$ binding without "cold" hapten being present (so called "binding control") the sensitivity of the reaction is about the reciprocal value of the affinity constant $\mathrm{K}$, i.e. $[\mathrm{H}] \approx 1 / \mathrm{K} \mathrm{mol} / 1$, where $[\mathrm{H}]$ is the minimal measurable hapten concentration [8]. This, however, is the theoretical sensitivity. For practical purposes the sensitivity should be calculated from the S.D. of replicate measurements at zero concentration. This real sensitivity is generally lower the 
maximal theoretical value, e.g. in the described cortisol assay $[4] 5 \times 10^{-2} \mu M$ vs. $0.16 \times 10^{-2} \mu M$.

\section{Materilals and methods}

The following binding agents have been studied in reactions with cortisol and other steroids: transcortin (cortisol binding globulin). A transcortin preparation was prepared from human blood serum by treatment with active charcoal and titration in several dilutions with a radioactive cortisol derivate as described elsewhere (9); anti-CSA rabbit serum. This antiserum is prepared by immunization of rabbits with cortisol-21-succinyl(bovine)-albumin (1); anti-COA rabbit serum. Raising and characterization is amply described (4) for this antiserum and the next two binding agents; (anti-COA serum)cellulose complex; solid phase I; (anti-COA serum IgG)-cellulose complex; solid phase II.

Steroids were dissolved in charcoal treated steroid free human blood serum. Solutions of four or more different concentrations in the range of $0.30-5.00 \mu \mathrm{M}$ were prepared for each steroid. In the study were involved cortisol, 11-desoxycortisol, $17 \alpha$-OH-progesterone, progesteron, pregnenolone, corticosterone, 11 -desoxycorticosterone, cortisone, tetrahydrocortisol (THF), dexamethasone and prednisolone.

Assay procedure. In the assay procedures with transcortin and anti-CSA serum the steroids were extracted from their solution with dichloromethane and an aliquot amount of the extract corresponding to $0.1 \mathrm{ml}$ of the serum solution was evaporated to dryness in a centrifuge tube.

When the anti-COA solid phasis I or II were used the steroid serum solution was diluted $1: 20$ with the assay buffer (phosphate $0.01 \mathrm{M} /$ citrate $0.02 \mathrm{M}$; ph 3.5 ). An amount of $0.1 \mathrm{ml}$ of this dilution was brought in a centrifuge tube; this corresponds to $5 \mu l$ of the original serum. The assay was performed in the centrifuge tubes as described earlier [4].

\section{Results}

From the data obtained in the experiments the concentration of bound steroid $B$ and the ratio of bound to free steroid $B / F$ in every tube was calculated. From the plots the affinity constants can be calculated. As may of the curves showed more or less deviation from linearity especially at high concentrations of steroid, we only look into account the initial (steep) slope of the curve corresponding to the first order reaction of steroid and protein.

The results of the investigation are tabulated in Table 1 , where both affinity constants and the ratio of every $K$ to $K$-for-cortisol are given.

From the same experiments the percentage interference in the cortisol determination for fixed concentration of binding protein and cortisol tracer (optimal conditions for cortisol determinations) can be calculated. These data are dependent on the said concentrations (Table II) and are best reliable in the cortisol range from $0.25-3.00 \mu M$. Similar tables are found in the literature on steroid analysis [10]. 

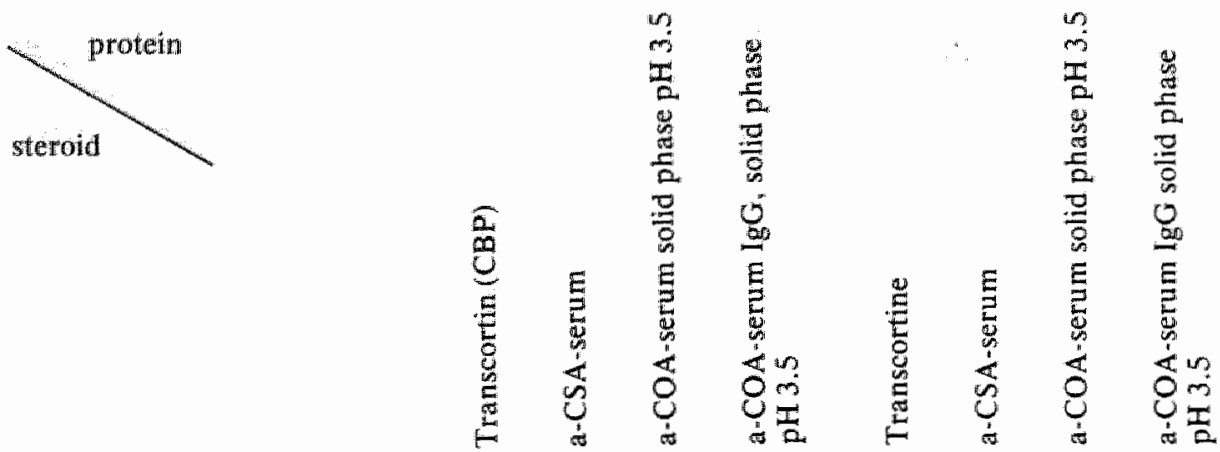

\begin{tabular}{rl}
\hline 1 & Cortisol \\
2 & $11-$ Desoxycortisol \\
3 & -OH progesteron \\
4 & Progesteron \\
5 & Pregnenolon \\
6 & Corticosteron \\
7 & $11-$ Desoxycorticosteron \\
8 & Cortison \\
9 & THF \\
10 & Dexamethason \\
11 & Prednisolon
\end{tabular}

$0.31 \quad 0.68$

$3.24 \quad 6.30$

100

100

$100 \quad 100$

$\begin{array}{llllllll}0.33 & 0.65 & 2.20 & 2.66 & 107 & 96 & 68 & 42\end{array}$

$\begin{array}{llllllll}0.18 & 0.21 & 1.20 & 1.62 & 58 & 31 & 37 & 26\end{array}$

$\begin{array}{llllllll}0.06 & 0.18 & 0.40 & 1.08 & 19 & 26 & 12 & 16\end{array}$

$\begin{array}{llllllll}0.00 & 0.00 & 0.00 & 0.00 & 0 & 0 & 0 & 0\end{array}$

$\begin{array}{llllllll}0.31 & 0.13 & 0.48 & 0.76 & 100 & 19 & 15 & 12\end{array}$

$\begin{array}{llllllll}0.17 & 0.34 & 0.41 & 1.23 & 58 & 50 & 12 & 19\end{array}$

$\begin{array}{llllllll}0.06 & 0.20 & 0.40 & 0.48 & 19 & 29 & 12 & 8\end{array}$

$\begin{array}{llllllll}0.06 & 0.20 & 0.40 & 0.48 & 19 & 29 & 12 & 8 \\ 0.08 & 0.18 & 0.54 & 0.26 & 26 & 26 & 17 & 4\end{array}$

11 Prednisolon

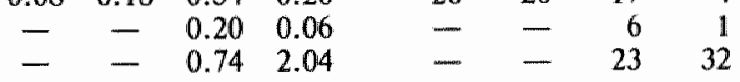

\section{Table II}

Percentage interference of steroids in cortisol determination

\begin{tabular}{lcccc}
\hline protein & $\begin{array}{l}\text { Transcortin } \\
\text { (CBP) }\end{array}$ & $\begin{array}{c}\text { a-CSA-serum } \\
\text { steroid }\end{array}$ & $\begin{array}{l}\text { a-COA-serum } \\
\text { solid phase } \\
\text { pH 3.5 }\end{array}$ & $\begin{array}{l}\text { a-COA-serum } \\
\text { IgG solid phase } \\
\text { pH 3.5 }\end{array}$ \\
\hline 1 Cortisol & 100 & 100 & 100 & 100 \\
2111 -Desoxycortisol & 97 & 99 & 63 & 47 \\
317 -OH progesteron & 58 & 30 & 30 & 15 \\
4 Progesteron & 13 & 41 & 13 & 12 \\
5 Pregnenolon & 0 & 0 & 0 & 00 \\
6 Corticosteron & 85 & 23 & 16 & 8 \\
7 11-Desoxycorticosteron & 62 & 46 & 15 & 10 \\
8 Cortison & 24 & 28 & 10 & 7 \\
9 THF & 24 & 6 & 8 & 0 \\
10 Dexamethason & - & - & 6 & 17 \\
11 Prednisolon & - & - & 31 & 0 \\
\hline
\end{tabular}




\section{Discusion}

The determination of affinity constants expressing the avidity of binding proteins for steroids is principally based on the law of mass action. This means that the determinations of these constants in heterogenous reaction media is not wholly correct. We are certainly aware of this fact, but nevertheless we think that for the purpose of comparison the performed method can be useful. That this is not more supposition is illustrated by the fact that the affinity constant for cortisol and transcortin is twenty times smaller than for cortisoll and (anti-COA)-IgG-cellulose (solid phase II), and that the determination of cortisol with solid phase II can best be performed with a serum aliquot of $5 \mu 1$ against $100 \mu 1$ with transcortin. The ratio $20: 1$ appears empirically and could be expected on a theoretical basis.

It should be mentioned here that the values obtained in the described way are really apparent affinity constants. The tracer used in all experiments was tritiated cortisol. The determination of true affinity constants of any steroid with the studied IgG should be performed with the appropriate tracers. However as our primary concern is the possible interference of other steroids in the cortisol assay, we think that the calculation of apparent affinity constants as described here meets our demands.

As can be read in Table $I$, there is a considerable difference in avidity of cortisolbinding steroids both for cortisol and for many other steroids. The relative aspecificity of transcortin, as demonstrated by equal affinity constants for cortisol, 11-desoxycortisol and corticosteron, was the immediate cause for the replacement of competitive protein binding by immunoassay. This was felt to be necessary especially in animal research, e.g. with rats, where the corticosteron content in blood often equals that of cortisol. Considerable gain was reached when the anti-CSA rabbit serum was available as a binding agent, but still differentiation between cortisol and 11-desoxycortisol was impossible. The synthesis of the immunogen $\mathrm{COA}$ and the raising of rabbit antiserum against this compound was another important step forward, which was even more favoured by the introduction of solid phase systems. Both sensitivity and specificity of the determination were considerable improved. It can be concluded that the best binding reagent now available is the solid phase II (anti-COA-IgG-cellulose) on account of specificity, sensitivity and ease of application (solid phase).

\section{References}

1 P.J. Brombacher, A.H.J. Gijzen, H.H.P. Janssens and M.P.J. Soons, Clin. Chim, Acta. 58 (1975) $173-176$.

2 A.H.J. Gijzen, P.J. Bronbacher, H.H.P. Janssens and S.H.C.M. Deckers, Clin. Chïm. Acta 58 (1975) 177-180.

3 A.H.J. Gijzen, Clin. Chim. Acta, $66(1976) 77-84$.

4 A.H.J. Gijzen, J. Mol. Med., 2 (1977) 99-111.

5 R. Malvatio, E. Rolleri and U. Rosa, in: RIA and related procedures in medicine, IAEA, Vienna 1974. pp. 455.479 .

6 G. Scatchard, Ann. N.Y. Sci., 51 (1949) 660-672.

7 R.N. Pinkard and D.M. Weis, in D.M. Weis, Handbook of experimental immumology, Backwell, Oxford, 1973, pp. 16-16.21.

8 R.S. Yallow and S.A. Berson, in: In vitro procedures with radioisotopes in medicine, IAEA, Vienna 1970 , pp. 455-479.

9 P.J. Brombacher, Stimulatie van de bijnierschors met 18-ACTH, Thesis, Amsterdam, 1975, pp, I6-22.

10 A. Vermeulen, in: H. Brever, D. Hamell and H.L. Kruskemper (Eds.), Methoden der Hormonbestim mung. Thiene, Stuttgart, 1975, pp. 169.175. 


\section{General survey and condusions}

Studies of the data obtained by competitive protein analysis (using transcortin of human origin) of the cortisol content in human plasma showed the lack of specificity of this method. For this reason we tried to obtain an antiserum with avidity for cortisol to be used as a binding protein in radio immuno assay, the underlying principle being antibody-hapten reaction.

In the first article (I) reproduced here the synthesis of the antigen cortisol-21succinyl-albumin ( $\mathrm{CSA}$ ) is described in detail. The yield of the antigen is quite satisfactory $(67 \%$ of the theoretically obtainable amount). Characterization is done in several ways, showing the purity and homogeneity of the antigen; moreover, the number of cortisol molecules bound to each molecule of albumin is shown to be 28 .

As expected, the product could be used to raise cortisol-binding antibodies in rabbits. Specific antibodies directed against the cortisol moiety of the antigen could be elearly demonstrated both by immunodiffusion and by titration with radioactively labelled steroid.

The specificity of the antiserum was compared with that of transcortin against a number of cortisol-related steroids. The antiserum was more selective than a transcortin preparation.

However, in order to investigate the antiserum more closely the particular cortisolbinding immunoglobulin was isolated and purified by affinity chromatography on a sepharose-CSA complex as described in the nexte article (II).

A procedure for the synthesis of the solid phase was dieveloped using sepharose- $4 \mathrm{~B}$ $\mathrm{CNBr}$ similar to the one already described by us in a paper on the coupling of intrinsic factor (1). In this way it was possible to isolate an IgG fraction consisting of at least two immunoglobulins, one binding BSA and the other specifically directed against CSA. It was possible to remove the former one by adding an excess of BSA (so-called adsorption) and removing the IgG-BSA complex by centrifugation, leaving the CSA-binding IgG behind in solution.

In the third article (III) is described how the cortisol-binding IgG can be isolated in a fraction which does not contain BSA-binding IgG. This is performed by affinity chromatography on cortisol-aminoalkyl-sepharose. Because this support contains no protein components, the BSA-binding IgG is not retained on the column. However, all cortisol-binding proteins from the rabbit antiserum are captured, i.e. not only the cortisol-binding $\operatorname{lgG}$ but also some albumin and a very small amount of $\alpha$-globulin, which is probably the rabbit transcortin. Immuno-electrophoresis of the isolated proteins against polyvalent goat anti-rabbit serum showed the presence of these proteins in the eluate. An attempt was made to increase the yield of cortisol-binding immuno-globulin in the affinity chromatography isolation procedure by "stripping" the antiserum, prior to chromatography, with charcoal. The hypothesis was that the antiserum, to some extent, might already in vivo be loaded with cortisol. It was expected that this cortisol-loaded IgG will not bind to the cortisol-aminoalkyl-sepharose and is lost in the isolation procedure. A real increase in cortisol-binding $\mathbb{I g G}$ from charcoalstripped antiserum could not, however, be demonstrated. This might be explained by the non-validity of the said hypothesis or by losses of immunoglobulin in the charcoal stripping procedure. Another explanation may be that there is so high a binding force of cortisol to the particular IgG that charcoal stripping is not possible; this is then clearly in contrast to the weakness of the binding force of cortisol to transcortin. Moreover, if this cortisol-IgG bond is of such intensity, it is possible that in charcoal treatment of the antiserum the cortisol-IgG complex as such is extracted from the serum. There is no firm experimental evidence available for these suppositions. 
The IgG isolated was characterized as described before and also in an extra study by labelling the $\operatorname{IgG}$ with iodine-125. The radioactively labelled $\mathrm{IgG}$ has the same characteristics in affinity chromatography as the "cold" IgG and can thus be purified in the same way. The possibility of using the labelled compound in an immuno-radiometric assay is considered.

Although, for use in protein-binding assays, the superiority of a cortisol-binding immunoglobulin over transcortin was clearly proven, the antiserum viz. IgG itself was not wholly satisfactory. There was still considerable cross-reactivity towards other steroids structurally related to cortisol. For this reason, we thought it worthwile to raise an antiserum in rabbits using a completely different antigen. In CSA, the hapten was coupled to the protein carrier, bovine serum albumin, via the side chain. The new antigen was synthesized through the 3-carboxymethyloxim of cortisol. The synthesis and isolation of this antigen cortisol-3-carboxymethoxim-(bovine)-albumin (COA) and the raising of the appropriate antisera in rabbits is described in detail in article IV.

Characterization of the antigen is done as described earlier. It is calculated that the number of cortisol molecules bound per molecule of bovine serum albumin in this antigen (COA) is much larger (44 moles of cortisol/mole BSA) than in the CSA-antigen ( 28 moles of cortisol/mole BSA). A higher immunogenicity could be expected and was indeed demonstrated by the production of higher antiserum titres. The immunoglobulin was characterized as usual by immunodiffusion and immunoelectrophoresis. The antiserum was reactive not only to COA and BSA, as expected, but also in a minor extent towards CSA. In the Ouchterlony reaction there is a clear difference between the precipitation lines in all three antiserum-antigen reactions. This suggests that the reaction of our new antiserum with CSA (the "former" antigen) is really directed towards the cortisolmoiety of the CSA and not towards the BSA-moiety (see Appendix I).

In order to prevent the coupling of albumin and transcortin from the antiserum to the cortisol-sepharose derivates in affinity chromatography, the latter was preceeded by isolation of the $\gamma$ globullin fraction via ion exchange chromatography over DEAE cellulose. Isolation of specific IgG was performed by affinity chromatography without concomittant binding of non-IgG cortisol binding proteins.

Another interesting feature in the determination of plasma cortisol is the separation of free and bound tracer. Problems of imcomplete separation are encountered in most generally used methods, e.g. coated charcoal or silicate adsorption procedures. We decided to bind the raised antiserum to cellulose as is described in detail in article IV. In order to increase the avidity of the solid phase for cortisol, the same is done with the IgG-fraction of the antiserum. We planned to increase the avidity still further by preparing a solid phase consisting of specific cortisol-binding $\mathrm{IgG}$ bound to cellulose.

However, at the time of the investigation this idea was abandoned on account of the large amount of antiserum needed and the excellent results already obtained with the cellulose-total-IgG solid phase.

The avidity of the different binding agents prepared was then determined and compared in terms of affinity constants of the reaction of the binding agents with cortisol. The cross-reactivity of 11-desoxycortisol in these reactions was studied simultaneously.

At the generally used $\mathrm{pH} 7.4$ of the reaction medium a fivefold increase of the affinity constant for the coupling of cortisol to antiserum was obtained when the latter was itself coupled to cellulose (solid phase I: cellulose-antiserum complex).

However, it was not possible with this solid phase to capture cortisol directly in the human serum sample to be analysed. This was thought to be due to so-called protein effects, of which the binding of cortisol to transcortin in the sample and the inhibition of 
the cortisol-solid phase 1 coupling reaction by nonspecific proteins from the sample must be mentioned.

These effects were eliminated by lowering the $\mathrm{pH}$ of the reaction medium to 3.5 . However, this has an effect on the main reaction; the affinity constant of the reaction of solid phase I with cortisol in a protein free medium drops by a factor 2.5 . In a protein containing medium the affinity is still lower but, in contrast to the reaction at pH 7.4, the cortisol is now quite well captured from the added serum sample. Using the solid phase, cortisol is better captured than when the antiserum is used in solution, regardless of the $\mathrm{pH}$, using coated charcoal for the separation of free and bound tracer.

A twofold increase in the affinity constant is observed when the cellulose-IgG (solid phase II) is used a binding agent. This solid phase II is now routinely used for the cortisol determination in human serum, without steroid extraction, as mentioned in the detailed deseription of the procedure (Appendix II). The overall sensitivity of the determination method as compared with the original procedure using transcortin, is now increased twenty-fold.

The specificity of the method (article V) was investigated by determining the apparent affinity constants of cortisol and ten other steroids with the binding agents transcortin, anti-CSA serum, anti-COA serum-cellulose complex (solid phase I) and anti-COA-IgG-cellulose complex (solid phase II). Expressing the K-values obtained as percentages of the affinity constant for the reaction of cortisol clearly demonstrates that the solid phase II (anti-COA serum IgG cellulose complex) is the better binding agent, with which cross-reactivity is lowest. The difference in avidity for 11-desoxycortisol between the solid phases is thought to be due to the presence of cellulose-bound transcortin in solid phase $\mathrm{I}$. 


\section{FURTHER CHARACTERIZATION OF THE IgG FROM THE COA-ANTISERUM}

The use of COA as an antigen in the raising of immunoglobulins in rabbits is described in article IV. It was demonstrated (article IV, fig. 3) that the antiserum is reactive towards the antigen COA and also towards BSA. This is of course not very surprising, as polyclonal antibody formation could be expected. In the Ouchterlony immunodiffusion experiment partial identity of the immunoglobulins in the reaction with COA and BSA was detected. In the present communication this is further investigated and elucidated.

The IgG-fraction from the antiserum was isolated by ion exchange chromatography over DEAE-cellulose. This IgG showed the same characteristical immunoprecipitation pattern (fig. 1) as the whole antiserum.

For further purification the lgG-fraction was subjected to affinity chromatography over cortisol-3-oxim-alkylsepharose. This immunosorbent contains no albumin and capturing of immunoglobulins via antigenic determinants for albumin could thus be prevented.

The supposition was that in this way an immunoglobulin fraction would be obtained which was characterized by avidity for the cortisol-oxim structural group.

In Ouchterlony immunodiffusion experiments those immunoglobulins were strongly reactive for COA but they partially still showed a clear reaction with BSA (fig. 2). The latter fact is rather surprising but can be explained by the hypothesis that the antigenic determinants on some immunoglobulins are characterized by affinity for the cortisol-albumin coupling site in the antigen molecule. This theory is supported by the consideration that it is virtually unlikely that proteins without specific avidity for cortisol are withheld in the affinity chromatography procedure used here. The antialbumin activity in the IgG fraction obtained in this procedure therefore must be related to cortisol avidity of the same immunoglobulins.

Another possibility might be that the amount of IgG eluted from the column with a glycine buffer of pH 2.8 (as used here) is only a fraction of the total amount of IgG captured by the immunosorbent. It is not impossible that other cortisol-binding immunoglobulins are bound much stronger to the immunosorbent than the fraction eluted and investigated. This fraction in itself is already heterogeneous as was shown in (fig. 2). The existence of immunoglobulins with different affinity constants for the immunosorbent might well be explained by the possibility of structurally different antigenic determinants in the polyclonal antiserum IgG.

If this second theory is right it should be possible to elute these stronger bound immunoglobulins in some way. This is still under investigation. A major difficulty in this type of study is that the amounts of active material involved are extremely small. 


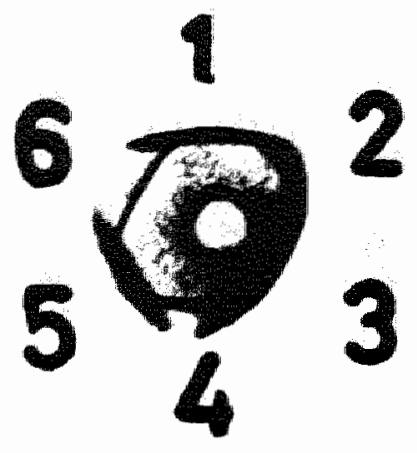

Fig. 1. Immunodiffusion of the IgG (centre well) against COA $(1,3,5)$ and $\operatorname{BSA}(2,4,6)$, see text.

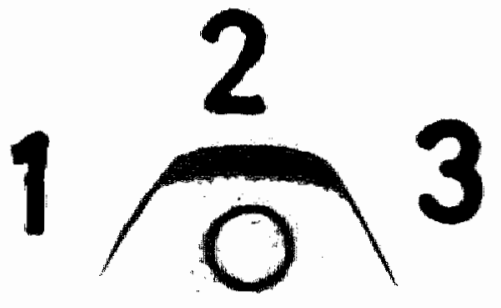

Fig. 2. Immunodiffusion of specific IgG (centre well) against $\mathrm{COA}(2)$ and against BSA (1 and 3). 


\section{DIRECT SOLID PHASE RADIO IMMUNO ASSAY OF CORTISOL IN BLOOD SERUM}

In a direct solid phase radio immuno assay of cortisol in blood serum, the latter is added as such to the incubation medium. This contains a fixed amount of tritiated cortisol as a tracer, and a quantity of cellulose-coupled-IgG (cortisol binding antibody raised in rabbits) capable of binding $50 \%$ of the tracer in the absence of unlabelled cortisol.

The amount of tracer bound is determined by the concentration of added cortisol; the competition between tracer and cortisol in the reaction with the solid phase is governed by the law of mass action as far as this can be applied on the heterogeneous reaction system.

The solid phase binding agent can mut. mut. also be used in a reaction system containing an iodinated cortisol-3-oxim derivative as a tracer.

\section{Reagents}

\section{Phosphate-citrate buffer}

1.618 gram of disodiumphosphate. 2 aq. $(9.09 \mathrm{mmol})$ and $4.394 \mathrm{gram}$ of citric acid. 1 aq. ( $20.9 \mathrm{mmol}$ ) are dissolved in water and the total volume is made up to $1000 \mathrm{ml}$. Total molarity $0.03 ; \mathrm{pH} 3.5$.

\section{Scintillation liquid}

To $690 \mathrm{ml}$ of Triton X-100 (Fisons) the scintillation liquid Insta-Fluor [Packard; mixture for organic substances containing dibutylphosphate (MDBP), diphenyloxazole (PPO) and p-bis(o-methylstyryl)benzene (bis MSB) $\mid$ is added to a final volume of $2000 \mathrm{ml}$; mix thoroughly.

\section{Tracer-buffer}

$[1.2-3 \mathrm{H}]$-cortisol, specific activity $40-50 \mathrm{Ci} / \mathrm{mmol}$, is dissolved in the phosphatecitrate buffer to an activity of about $0.15 \mu \mathrm{Ci} / \mathrm{ml}$.

4. Steroid free serum

Fresh clear normal sera are pooled and mixed by rotation with $50 \mathrm{mg} / \mathrm{ml}$ of activated charcoal at $4^{\circ} \mathrm{C}$ during 48 hours.

Afterwards the charcoal is precipitated by centrifugation and the supernatant serum filtered through a cellulose-nitrate filter (Millipore), pore size $0.25 \mathrm{~m} \mu$.

The charcoal is activated by heating "Norit R 0.8 extra" at $120^{\circ} \mathrm{C}$ during 2 hours.

\section{Cortisol standard solution}

A stock solution of cortisol in aethanol $(10 \mathrm{mmol} / \mathrm{l})$ is diluted $1: 10$ with phosphatecitrate buffer. This solution is dilluted again 1:10 with steroid free serum (charcoal stripped human serum) so that the final cortisol concentration is $100 \mu \mathrm{mol} / 1$.

Working standards are prepared, by further dilution with steroid free serum, to contain viz. $5.00 ; 3.00 ; 2.00 ; 1.00 ; 0.50 ; 0.25$ and $0.125 \mu \mathrm{mol}$ cortisol per liter.

\section{Solid phase IgG-cellulose}

The IgG fraction (about $13-15 \mathrm{mg}$ ) is obtained from $0.5 \mathrm{ml}$ antiserum by chromatography, over DEAE cellulose (Pharmacia A 50) and then covalently coupled to cellulose activated by cyanogen bromide.

The solid phase $(500 \mathrm{mg})$ is suspended in $100 \mathrm{ml}$ of buffer and the quantity needed in 
the assay is determined by titration, usually this appears to be $0.2-0.3 \mathrm{ml}$ of suspension per tube.

\section{Assay}

$50 \mu \mathrm{l}$ of patients serum or cortisol working standard are diluted with $1.0 \mathrm{ml}$ of phosphate citrate buffer in order to contain $5 \mu 1$ sample in $0.1 \mathrm{ml}$ dilution.

In polystyrene tubes are brought together

0.2 or $0.3 \mathrm{ml}$ of solid phase suspension

$0.1 \mathrm{ml}$ of diluted serum or standard

$0.1 \mathrm{ml}$ of tracer-buffer

phosphate-citrate buffer ad $0.6 \mathrm{ml}$.

The mixture is rotated at ambient temperature during 90 minutes, whereupon the solid phase is precipitated by centrifugation.

An $0.8 \mathrm{ml}$ aliquot of the supernatant is mixed with $10 \mathrm{ml}$ of scintillation liquid and the radioactivity measured.

The radioactivity of the standards is plotted against their known values and the unknows are read from this graph.

\section{Accuracy}

By lack of an outstanding reference method for the determination of cortisol "true values" in sera the accuracy has been assessed by recovery studies. The coefficient of correlation between expected and found values is 0.998 .

\section{Precision}

The precision of the method has been calculated from duplicate values. The coefficient of variation initially was $8.0 \%$. After the introduction of excellent diluting equipment the coefficient of variation is now $3 \%$.

\section{Sensitivity}

The sensitivity of the method is defined as the lowest possible value which is significantly different from zero. This is assessed by running duplicate zero estimations and determining the standard deviation $S_{D}$. The sensivity is now twice $S_{D}$ and appears to be $0.05 \mu \mathrm{mol} / 1$.

\section{Specifficity}

The specificity of the method is described in detail elsewhere (article V).

\section{Normal values}

Normal values for both sexes at $9 \mathrm{hr}$ a.m. range $0.23-0.73 \mu \mathrm{mol} / 1(\mathrm{x} \pm 2 \mathrm{~S}$; $\mathrm{n}=35$ ). 


\section{Summary}

In five articles investigations were described on the use of immunoglobulins in the radioimmunoassay of cortisol in human serum.

The first article gives details of the synthesis of an antigen, cortisol-21-succinylalbumin (CSA), and the raising and characterization of the corresponding antiserum in rabbits.

The second paper describes the isolation and purification of the cortisol-binding immunoglobulin by affinity chromatography using sepharose-CSA as immunosorbent. and the synthesis of the latter.

Further investigations in this field are reported in the third article, where DEAE-cellulose chromatography and affinity chromatography (and the synthesis of the immunosorbent) using sepharose-alkylamino-cortisol results in the direct isolation of the particular immunoglobulin without contamination with other $\lg G$ fractions, such as BSA-binding globulin. Labelling of the isolated cortisol-binding $\mathbb{I g G}$ with iodine-125 is described.

Problems of specificity and sensitivity of the radioimmunoassay of cortisol were differently approached (articlle IV) by synthesizing the antigen cortisol-3carboxymethoxim-albumin (COA), and using it for the production of antiserum in rabbits. This antiserum possesses a considerably higher titre and appears to be more specific for cortisol than the first antiserum.

Important technical progress is made by employing cellulose-bound IgG as a solid phase in the direct assay of cortisol in serum at a lower $\mathrm{pH}$ value.

Finally, the influence of related steroids on the assay is described in article V.A general survey of the investigations and conclusions is presented.

Appendix I gives some new information on the immunological properties of the COA-antiserum.

In Appendix II a detailed procedure for the rapid direct estimation of cortisol in microsamples of human serum is described. 


\section{Samenvating}

In een wijftal artikelen zijn onderzoekingen beschreven over het gebruik van immunoglobulinen voor de radioimmunologische bepaling van cortisol in menselijk serum.

In het eerste artikel is de synthese van het antigeen cortisol-21-succinyl-albumine (CSA) beschreven alsmede het opwekken en karakteriseren van daartegen gerichte antilichamen bij konijnen.

In het tweede artikel is de afscheiding en zuivering van cortisol bindend immunoglobuline uit het genoemde antiserum nader toegelicht. Hierbij is gebruik gemaakt van affiniteitschromatografie, waartoe het antigeen CSA is gekoppeld aan sepharose.

In het derde artikel is uitvoeriger ingegaan op de isolatie van immunoglobulines uit antiserum met behulp van chromatographie, waarbij gebruik gemaakt is van DEAEeellulose en wan het meer specifieke cortisol-alkylamino-sepharose, ten einde koppeling van andere IgG-fracties als BSA-globuline te voorkomen. Bovendien is het merken van het geisoleerde cortisol bindend IgG met ${ }^{125}$ I beschreven, waardoor een nadere karakterisering van genoemd eiwit mogelijk was.

Het volgend artikel (artikel IV) beschrijft een andere benadering van de problematiek van specificiteit en gevoeligheid van de radioimmunologische bepaling. Hierbij is uitgegaan van het gebruik van een ander antigeen, cortisol-3-carboxymethoximalbumine (COA), hetgeen gebruikt is voor de opwekking van een tweede antiserum in konijnen. Het laatste bezit een hogere titer in de cortisolbindingsreactie en blijkt tevens meer specifiek te zijn.

In dit artikel is ook een zogenaamde solid-phase methode beschreven waardoor de scheiding van gebonden en ongebonden cortisol bij de radioimmunologische bepaling direct in serum kan plaatsvinden. Ten einde het zogenaamde eiwiteffect te onderdrukken wordt de reactie bij een relatief lage $\mathrm{pH}$ uitgevoerd.

In het vijfde artikel wordt de reactie van het laatstgenoemde antiserum respectievelijk het cortisolbindend IgG daaruit, al dan niet als "solid-phase" aan cellulose gebonden, beschreven ten opzichte van verschillende andere steroïden dan cortisol.

In Appendix I zijn enkele gegevens vermeld ter nadere karakterisering van het COA-antiserum.

In Appendix II is een snelle rechtstreekse methode voor de bepaling van cortisol in micro-hoeveelheden menselijk serum in detail beschreven. 


\section{Curriculum vitae A.H.J. Gỹzen}

Arnold Hubert Gijzen werd geboren te Geleen op 10 april 1932.

Hij volgde aldaar lager en middelbaar onderwijs (St. Michiel-College, diploma H.B.S.-B).

Vervolgens studeerde hij pharmacie aan de Rijksuniversiteit te Utrecht, waar hij in 1962 het doctoraal examen aflegde, in 1963 gevolgd door het apothekersexamen aan dezelfde universiteit.

De universitaire studie werd gedurende twee jaar onderbroken voor het vervallen van de militaire dienstplicht als motortransportofficier.

Van mei 1962 tot januari 1964 was hij als wetenschappelijk medewerker verbonden aan het Laboratorium der Nederlandse Apothekers te Utrecht.

Van januari 1964 tot maart 1969 werkzaam als assistent op de afdeling klinische chemie (hoofd: Dr. P.J. Brombacher) van het St. Joseph/De Wever-Ziekenhuis te Heerlen.

Sinds 1969 werkzaam als adjunct-hoofd van het isotopenlaboratorium van het De Wever-Ziekenhuis te Heerlen.

Dit proefschrift werd bewerkt op het isotopen- en klinisch chemisch laboratorium van het De Wever-Ziekenhuis te Heerlen. 